\title{
Chromium Crucible Steel Was First Made in Persia
}

\author{
Rahil Alipour ${ }^{1 *}$, Thilo Rehren ${ }^{2,3}$, and Marcos Martinón-Torres ${ }^{4}$ \\ ${ }^{1}$ Gerda Henkel Research Fellow, UCL Institute of Archaeology, London, WC1H OPY, UK. \\ ${ }^{2}$ A.G. Leventis Professor for Archaeological Sciences, The Cyprus Institute, 2121 Aglantzia Nicosia, Cyprus. \\ ${ }^{3}$ UCL Institute of Archaeology, London, WC1H OPY, UK. \\ ${ }^{4}$ Pitt-Rivers Professor of Archaeological Science, Department of Archaeology, University of Cambridge, CB2 3DZ, \\ UK. \\ *r.alipour@ucl.ac.uk
}

\section{Abstract}

For more than a century, evidence for the production of crucible steel in Central and Southern Asia, prior to the European Industrial Revolution, has fascinated and challenged material scientists, historians and archaeologists. At the same time, chromium-alloyed stainless steel was developed in the early $20^{\text {th }}$ century, building upon $19^{\text {th }}$ century experiments with low chromium steel. Here we demonstrate new evidence of the intentional addition of chromium to steel nearly a millennium earlier, as part of the Persian crucible steel (pulad) tradition including the production of low-chromium crucible steel in early $2^{\text {nd }}$ millennium CE Persia. We analysed archaeological finds from the $11^{\text {th }} \mathrm{C}$. CE site of Chahak in Iran showing the intentional and regular addition of chromium mineral to the crucible charge, resulting in steel containing around $1 \mathrm{wt} \%$ chromium. A contemporaneous crucible steel flint striker held in the Tanavoli Collection is reported to also contain chromium, suggesting its origin from Chahak. We argue that the mysterious compound 'rusakhtaj' from Biruni's $\left(10^{\text {th }}-11^{\text {th }} \mathrm{C}\right.$. CE) recipe for crucible steel making refers to the mineral chromite. Additional historical sources up to the mid-2 ${ }^{\text {nd }}$ millennium CE refer to crucible steel from Chahak as being particularly brittle, consistent with its increased phosphorous content.

Keywords: Crucible steel, Persian steel, Chromium steel, Scanning Electron Microscope, Archaeometallurgy, Islamic Archaeology, Manuscripts

\section{Introduction}

Crucible steel is the earliest liquid steel ( $<2 \%$ carbon) produced in history. Closed crucibles enable more homogeneous absorption of carbon into iron than the traditional bloomery process, and a complete separation of slag from steel (Craddock 1995, 278; 2003, 231-243; Craddock and Lang 2004, 35). Based on archaeological evidence, there are two known crucible steel making traditions, in Central Asia (Persian pulad), and South Asia (Indian wootz), while historical manuscripts record three methods of crucible steel making: carburization of bloomery iron by organic material, co-fusion of cast iron and bloomery iron, 
and de-carburization of cast iron. Persian crucible steel has been produced from at least the $10^{\text {th }}$ century CE (Rehren and Papakhristu 2000, 55; Papakhristu and Rehren 2002, 69) in today Uzbekistan and Turkmenistan by carburizing method, and some scholars argue that Turkmenistan's crucible steel making in Merv is of co-fusion (Herrmann and Kurbansakhatov 1995, Herrmann et al. 1996; Herrmann et al. 1997, 13; Feuerbach et al 1997; Feuerbach et al. 1998, 39; Simpson 2001).

The origin of Indian wootz is tentatively dated from the $3^{\text {rd }} \mathrm{C}$. BCE to the $3^{\text {rd }} \mathrm{C}$. CE based on some surface finds in Kodumanal site of Tamil Nadu (Srinivasan and Griffiths 1997), but no crucible lids or iron or steel prills were found, hence any future discussions are subject to providing enough evidence (Wayman and Juleff 1999; Feuerbach 2002). The South Indian wootz is created by two methods: carburization of bloomery iron with organic material in Mysore and Salem, and co-fusion of bloomery iron and cast iron in Hyderabad (17 ${ }^{\text {th }}$ C. CE) (Srinivasan 1994, 51-52; Craddock 1995, 282; Lang et al. 1998, 12; Juleff et al. $2014,1031)$. Sri Lankan crucible steel $\left(6^{\text {th }}\right.$ to $19^{\text {th }}$ C. CE) is all produced by carburisation, but

50 has a different origin than the South Indian carburizing method, and was perhaps developed separately from the South Indian traditions (Juleff 1990; 1998).

The carburizing method relied on the addition of organic matter to a charge of small iron fragments in closed crucibles which were then fired at temperatures exceeding $1200^{\circ} \mathrm{C}$, resulting in the formation of liquid steel and small amounts of slag. Early Islamic recipes often include the addition of specific mineral compounds in the charge, such as manganese oxide, calcium carbonate, and others (Hoyland and Gilmour 2006; Alipour and Rehren 2014). Most historical crucible steel artefacts are plain hypereutectic carbon steels, often containing phosphorous as an additional alloying element, but only very minor or trace amounts of siderophile transition metals used in modern steels, such as manganese, vanadium and chromium (Verhoeven et al. 1998). The few published analyses of Central Asian crucible steel slag show this to be rich in calcium and manganese oxide, consistent with the additives listed in historical recipes (Rehren and Papakhristu 2000, 57; Alipour 2017).

The crucible steel artefacts in major collections are mostly arms and armour and bladed weapons such as swords and daggers, often famed for the damascene pattern developed on their surface. They often lack well-documented provenance information or production dates, and their authenticity can be in question, particularly if elements considered to be typical of modern steel are present. This had been the case for an early Islamic flint striker in the Tanavoli Collection, with a published chromium content of more than 1 wt\% (Allan and Gilmour 2000, 437, 512). While on the balance of evidence this object is considered authentic, no comparable evidence for the production of such chromiumcontaining steel had been known to date. Therefore, determining the chemical composition of individual objects can assist in locating metal origin and potentially date of production, 
provided they match chemical characteristics of crucible steel from well-documented

production sites.

Here we present the physical evidence for the production of such low-chromium crucible steel from Chahak in southern Iran, the only known archaeological site within Iran's current borders to contain evidence of crucible steel making and associated smithing activities (Alipour 2017). This paper combines the reading of Biruni's crucible steel recipe $\left(10^{\text {th }}-11^{\text {th }} \mathrm{C}\right.$. CE) with the analysis of production remains from a ${ }^{14} \mathrm{C}$-dated context at Chahak. We conclude that Chahak provides the earliest evidence for the consistent and intentional addition of a chromium mineral, most likely chromite, to the crucible steel charge - resulting in the intentional production of a low-chromium steel.

\subsection{Archaeological context}

The identification survey of the site was aided by the historical manuscripts $\left(12^{\text {th }}\right.$ to $19^{\text {th }} \mathrm{C}$. CE) mentioning Chahak as a pulad production centre. From the $13^{\text {th }}$ century onwards Chahak pulad was noted for its fine and exquisite patterns; but its swords were brittle, hence lost their market value (Alipour and Rehren 2014, 241). Prior to this field survey, Chahak had been identified (but not excavated) by Iranian officials as either a Seljuq or

Safavid period site. Crucible steel making waste is scattered along the southern part of the village; and a deposit layer (mostly of broken crucibles), from which the crucible and slag fin samples of this research were retrieved has been preserved under a dirt road (exposed by ploughing for about 100 meters). About 50 meters to the north east of the dirt road, some tuyère remains were found; another 50 meters to the north west of the dirt road locates an area covered by smithing slags, suggesting furnace area and smithing workshops.

Some residual charcoal found within a broken crucible, and another one within a smithing slag were used for radio carbon dating (performed by Beta Analytic Radiocarbon Dating Lab). The results of both the crucible steel making and the smithing samples dated between $10^{\text {th }}$ to $12^{\text {th }}$ C. CE (see Alipour 2017, Appendix VI). This confirms a Seljuq date of the production of the material retrieved for this study. However, an important manuscript of the Ilkhanid period, and several other manuscripts belonging to later medieval and early modern period attest the continuation of the production well beyond the Mongol invasion and through the Safavid period (Alipour 2017, 155).

\subsection{Biruni's crucible steel making recipe $\left(10^{\text {th }}-11^{\text {th }} \mathrm{C}\right.$. CE)}

To date, at least ten Islamic manuscripts from the $8^{\text {th }}$ to $15^{\text {th }} \mathrm{C}$. CE are known to provide information on iron and/or steel, but only a few, dated from the $10^{\text {th }}$ to $12^{\text {th }} \mathrm{C}$. CE, present first-hand data on the crucible steel industry (Alipour 2017). The manuscript 'alJamahir fi Marifah al-Jawahir' ('A Compendium to Know the Gems', $10^{\text {th }}-11^{\text {th }}$ C. CE) is one of those, written by the Persian polymath Abu-Rayhan Biruni (1974, 1995; Al-Hassan 1978). 
110 The measurement units of the ingredients listed in his recipes are based on Islamic/medieval measuring systems that vary spatially and temporally. These weight units have been used over a long period of time and across a wide region, often representing different values; therefore, the exact amounts of the units at a specific time and place are difficult to determine. Consequently, some conversion factors were extracted based on

115 Dehkhoda (1993) and fact checked with Marcinkowski (2003), and after comparison with the archaeological-analytical results, the most corresponding conversion factor was chosen for each weight unit; however, we acknowledge that they are tentative.

Five ratl (4 kg) of horseshoes with their nails, which are made of narmahan, with 10 dirham (32 g) each of rusakhtaj, marqshisha talaie, and magnesia are put in a crucible, afterwards the crucible is luted with clay of wisdom and put in a furnace and the furnace will be full of charcoal and blown with Roman bellows that need two men, until it [the iron] melts and whirls. [Then,] bundles are added containing 40 dirham (128 g) ground mixture of equal amounts of halila (Myrobalans), pomegranate rinds, salt [used in] dough and oyster shells is thrown into each crucible. The crucibles must be blown non-stop for an hour, then heat must be stopped for the crucibles to cool down; and afterwards, the iron ingots are to be taken out from the furnace (Biruni 1974).

It is noteworthy that Biruni's recipe contains two possible errors, one is the twostage nature of the process, while this could not have been possible as the crucibles are and must remain sealed during the whole process. Additionally, the iron is mentioned to have molten before adding organic matter. On the other hand, some useful information on the nature of the ingredients and the crucible steel making method are compare to the analytical results of Chahak crucible steel.

\subsection{A note on using historical accounts in archaeology}

The interpretation of technical information from historical manuscripts is subject to problems beyond a simple language barrier (Martinón-Torres 2008). The language and the terms used to record technological processes or materials may not be used anymore or sometimes not have the same meaning and attribution as in the modern science (Principe 1987). Interpreting historical accounts as a source, one should note that historical recipes may not have been written by the craftspeople (Miller 2007, 37) (as is true with Biruni's account of crucible steel making), and most likely not even for the craftspeople. Technologies are mainly practice oriented, and craftspeople's knowledge was normally passed on through generations by apprenticeship and 'guided imitation' (Killick 2004, 73). Additionally, writing was socially restricted to elites (Moreland 2001, 20). The writer could have gathered old data or witnessed the process, both of which could lead to copying errors, lack essential parts of the operational sequence, or were not accurate (in modern 
terms) at some other levels or details. Therefore, interpreting requires extra caution, and has to be done in conjunction with other evidence such as archaeological and scientific data.

\subsection{Aims and methods}

The primary aim of this research is to understand the production process of Chahak crucible steel, in comparison with the historical recipe of crucible steel making by Biruni (10$11^{\text {th }} \mathrm{c}$. CE). The technical analysis includes macro and microanalyses of Chahak crucible steel making materials, most of which were retrieved from the exposed archaeological layer, and the tentative smithing and furnace area. The material analysed include crucible fragments, crucible slag fins, smithing slags, a bloomery iron, and a couple of tuyère fragments.

Methods used are: morphological and macro- analysis of about 200 crucible fragments that resulted in theoretical reconstruction of the crucibles; microanalysis of polished resin block samples with Optical Microscope (OM); and chemical analysis by Scanning Electron Microscope (SEM-EDS). The data quality was tested and documented by measuring three certified reference materials (CRMs) (fused basalt standards: BHVO-2, BCR-2 and BIR-1) similar to the metallurgical samples' composition. The results and more information on the methods can be found in the online supplementary data. The SEM-EDS data was normalised and images taken in backscattered electron (BSE) mode.

The metallic iron in the slag fin, smithing slag and the bloom, incorporate the most significant elements that can help identify the process and further investigate the type of iron used as the raw material and type of ingot produced. But as the samples are carbon coated, carbon is checked out of the EDS calculation, thus the carbon content specifically in the iron prills could not be quantitatively analysed, and is not reported in the final composition reports. Subsequently, the established etching method (Nital 2\% recommended in Scott 1991, 67, and used to treat iron surfaces in Blakelock 2012) was used to obtain a qualitative analysis of the carbon content of the iron present in the slags. For this purpose, one smithing slag, a sample of the bloom, and a slag fin sample were used.

\section{Results and discussion}

\subsection{Technical ceramics}

Chahak crucibles hold a distinct cylindrical structure with a tentatively reconstructed height of $27 \mathrm{~cm}$ (without the lid) and average internal diameter of $6.7 \mathrm{~cm}$. They consist of three main parts: cylindrical body, a flat disc-shaped pad, and a hemispherical lid (Fig. 1a, b $\& c)$. The ceramic is dense, highly vitrified and grey-ish with argillaceous fragments of similar composition to the matrix. The crucible body and lid are highly refractory with an alumina content in excess of $25 \mathrm{wt} \%$; however, their iron content is relatively high but reduced to 
iron droplets within the entire matrix of the crucible (Fig. 2a \& b). In contrast, the crucible pads are low in alumina and highly calcareous. They are not vitrified and their iron oxide has not been reduced to metal, giving the pads a reddish colour (Fig. 3) (Table 1).

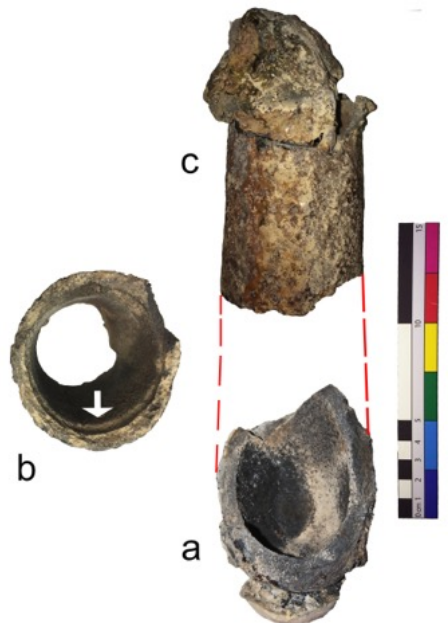

Figure 1. Reconstructing a Chahak crucible with a. crucible base, featuring the base pad in the bottom; b. middle part of the crucible with slag line (due corrosion by molten slag) on the inner wall (marked by arrow), where is mostly where the crucibles break easily following by a blunt force to take the ingot out; and $\mathbf{c}$. the upper part of the crucible with the lid still adhering to it.

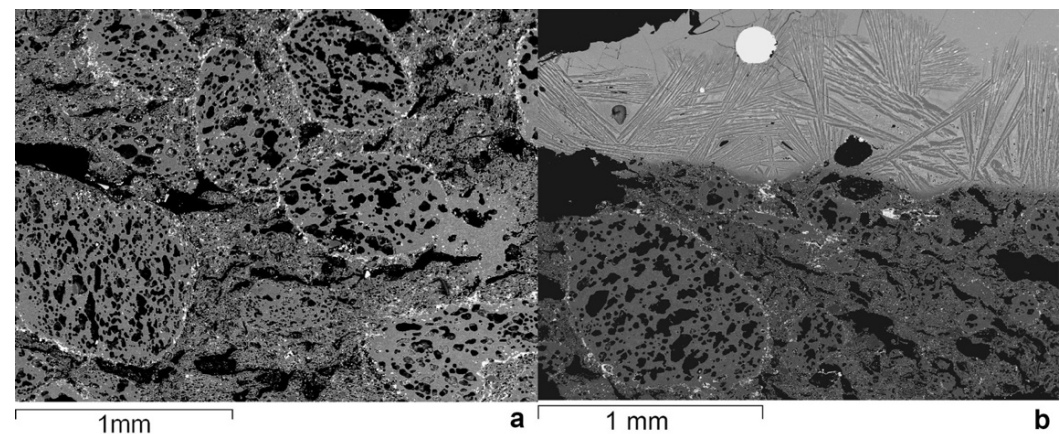

Figure 2. BSE images of a. crucible wall matrix exhibiting argillaceous fragments with iron content reduced to prills around the edges of the fragments; $\mathbf{b}$. the crucible-slag interface featuring the reduced iron content of the crucibles and the distinct argillaceous fragment, and the slag crystallised at the point of contact with a large metallic prill. 


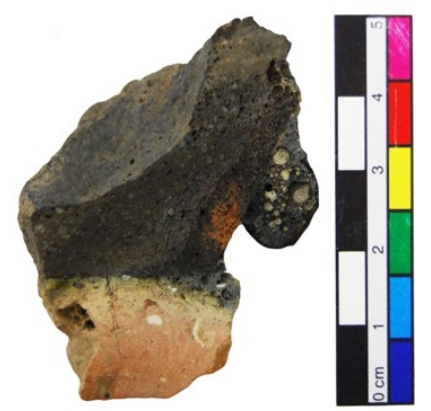

Figure 3. Cross section of a crucible base fragment showing the reddish clay of the crucible pad and the blackish crucible base/body

From a potential furnace area in Chahak, two tuyère samples were retrieved and analysed for their type of clay. In comparison to the crucible ceramic, the average composition of the tuyères contains higher alkaline earth elements, while alumina is lower by about $10 \%$. This highlights a completely different clay type used for the crucibles. In addition, a total of five domestic pottery sherds were analysed. They also have lower silica and alumina content and elevated lime (Table 1).

Table 1. Elemental composition of Chahak crucible walls, lids, tuyères, domestic pottery and pad (average of multiple SEM-EDS area analyses, reported in wt $\%$, normalised to $100 \%$ - elements below detection limit: blank) ( $n=$ number of samples, $x=$ number of analyses in total)

\begin{tabular}{lcccccccccc} 
& $\mathrm{Na}_{2} \mathrm{O}$ & $\mathrm{MgO}$ & $\mathrm{Al}_{2} \mathrm{O}_{3}$ & $\mathrm{SiO}_{2}$ & $\mathrm{~K}_{2} \mathrm{O}$ & $\mathrm{CaO}$ & $\mathrm{TiO}_{2}$ & $\mathrm{MnO}$ & $\mathrm{FeO}$ & $\mathrm{n}=\mathrm{x}$ \\
\hline Lid & 0.6 & 1.1 & 26.5 & 61.1 & 1.6 & 1.4 & 1.6 & & 6.3 & $10=19$ \\
Wall & 0.6 & 0.8 & 27.2 & 60.7 & 1.5 & 1.2 & 1.5 & $<0.6$ & 6.4 & $9=22$ \\
Pad & 1.2 & 2.5 & 9.2 & 55.1 & 1.7 & 25.7 & 0.6 & & 4.2 & $1=4$ \\
Tuyères & 1.4 & 4.4 & 14.7 & 62.7 & 3.0 & 6.0 & 0.7 & & 7.2 & $2=8$ \\
Domestic pottery & 1.7 & 3.2 & 13.7 & 56.8 & 2.5 & 14.7 & 0.8 & & 6.4 & $5=14$
\end{tabular}

\subsection{Slag fins, smithing slags and the bloom}

The 15 slag fins' compositions are dominated by silica (average $44 \mathrm{wt} \%$ ), alumina and lime (average $17 \mathrm{wt} \%$ each) in a 2.5:1:1 ratio respectively (Table 2). Since the metallic iron 210 does not influence the slag composition and behaviour, iron prills were not included in the bulk analyses of the slag. Iron oxide is surprisingly low (average $1.9 \mathrm{wt} \%$ ), as a consequence of the very high inferred $\mathrm{CO} / \mathrm{CO}_{2}$ ratio. This is one of the most distinctive features of crucible steel making slags from bloomery iron slags. Iron is also present as metallic prills within the slag matrix (Fig. 4a-f). Manganese oxide is systematically present in the slag (4 wt\% to 19

$215 \mathrm{wt} \%$, average $12 \mathrm{wt} \% \mathrm{MnO}_{2}$ ) and is known to be one of the characteristics of Central Asian crucible steel slag fins (Rehren and Papakhristu 2000, 57; Feuerbach 2002, 77). The distinctive element in Chahak slag fins is chromite (average $1.1 \mathrm{wt} \%$ ), which has not been previously reported in other crucible steel making systems. 
been reported separately in Alipour and Rehren (2014), showing them to be compositionally similar. Accordingly, they were merged here, providing an overall average composition for each sample.

$\begin{array}{lcccccccccccc}\text { Samples } & \mathrm{Na}_{2} \mathrm{O} & \mathrm{MgO} & \mathrm{Al}_{2} \mathrm{O}_{3} & \mathrm{SiO}_{2} & \mathrm{SO}_{3} & \mathrm{~K}_{2} \mathrm{O} & \mathrm{CaO} & \mathrm{TiO}_{2} & \mathrm{Cr}_{2} \mathrm{O}_{3} & \mathrm{MnO} & \mathrm{FeO} & \text { \#Analyses } \\ \text { W62 } & 0.5 & 4.9 & 16.1 & 40.7 & <0.4 & 3.3 & 23.7 & 0.9 & 1.3 & 7.2 & 1.0 & 2 \\ \text { W67 } & 0.7 & 2.2 & 17.4 & 41.2 & <0.6 & 1.5 & 10.7 & 0.9 & 0.8 & 19.3 & 5.1 & 8 \\ \text { W73 } & 0.5 & 3.1 & 19.6 & 44.5 & & 1.2 & 14.1 & 1.0 & 1.5 & 13.4 & 1.1 & 6 \\ \text { W80 } & 0.5 & 5.9 & 18.3 & 47.1 & & 1.5 & 19.5 & 1.2 & 0.4 & 5.4 & 0.6 & 3 \\ \text { W84 } & 0.5 & 4.2 & 16.6 & 42.9 & <0.7 & 2.5 & 16.4 & 0.9 & 0.6 & 11.8 & 3.6 & 2 \\ \text { W85 } & 0.5 & 2.1 & 17.5 & 41.1 & <0.5 & 1.0 & 18.4 & 0.9 & 1.5 & 14.6 & 2.4 & 6 \\ \text { W92 } & 0.7 & 3.5 & 15.0 & 43.7 & <0.6 & 2.1 & 16.5 & 0.8 & 0.9 & 14.7 & 2.0 & 9 \\ \text { CS1 } & 0.6 & 4.3 & 17.1 & 46.3 & & 1.3 & 21.1 & 1.1 & 0.8 & 6.8 & 0.7 & 3 \\ \text { CS2 } & 0.6 & 4.1 & 17.0 & 44.6 & <0.5 & 2.7 & 18.2 & 1.0 & 1.2 & 8.9 & 2.2 & 5 \\ \text { CS3 } & 0.5 & 5.2 & 17.0 & 44.0 & <0.5 & 1.8 & 18.2 & 1.0 & 0.3 & 11.1 & 0.7 & 6 \\ \text { CS4 } & 0.4 & 3.8 & 16.7 & 42.2 & & 1.6 & 13.5 & 1.0 & 1.2 & 17.2 & 2.5 & 7 \\ \text { CS5 } & 0.7 & 4.9 & 16.9 & 44.9 & & 2.5 & 21.4 & 1.0 & 1.5 & 5.3 & 0.9 & 5 \\ \text { CS6 } & 0.5 & 3.6 & 19.5 & 43.6 & & 1.7 & 11.9 & 1.1 & & 17.2 & 0.9 & 2 \\ \text { CS7 } & 0.7 & 7.0 & 16.0 & 44.1 & & 2.5 & 22.1 & 1.2 & 2.2 & 4.4 & 0.8 & 5 \\ \text { CS8 } & 0.5 & 4.2 & 18.5 & 44.5 & & 2.2 & 17.8 & 1.0 & 0.5 & 10.0 & 0.9 & 4 \\ \text { Average } & 0.6 & 4.0 & 17.1 & 43.5 & <0.3 & 1.9 & 17.0 & 1.0 & 1.1 & 12.1 & 1.9 & 73\end{array}$
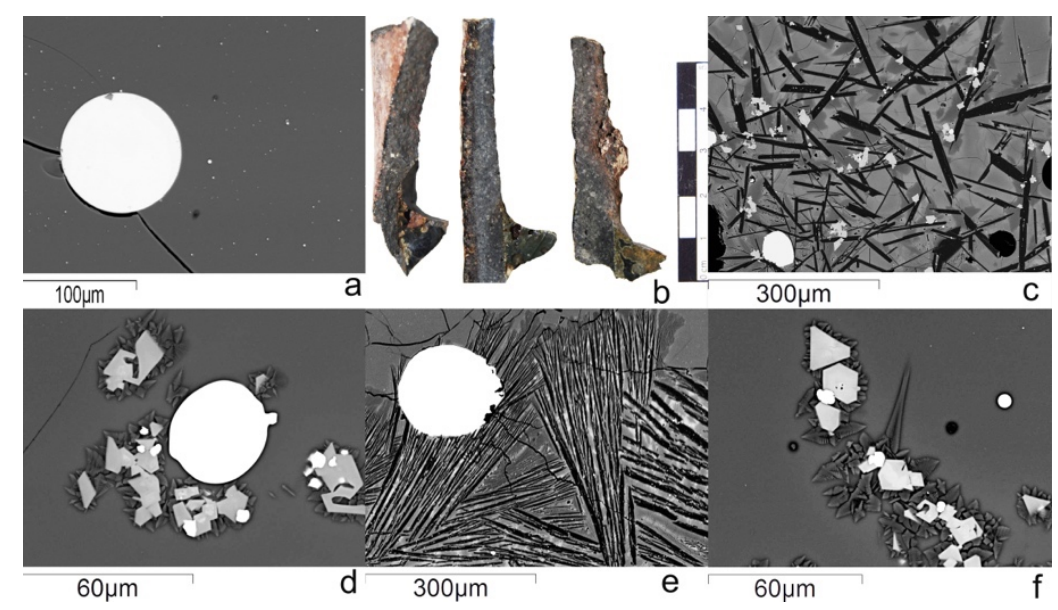

Figure 4. Images of Chahak slag fins (SEM images are all BSE): a. the BSE image showing metallic prills of various sizes; $\boldsymbol{b}$. Chahak crucible fragments with slag fins adhering to their interior; $\mathbf{c}$. BSE image features dark anorthite crystals, some lighter grey colour chromite spinels and metallic prils; $\boldsymbol{d}$. a large metallic prill surrounded by chromite spinels and smaller prills in a glassy matrix; $\mathbf{e}$. metallic prill in a crystalline matrix; $\mathbf{f}$. freshly grown chromite spinels in light grey in glassy matrix, with some small metallic prills.

Chromite is present primarily in the form of freshly grown (euhedral cubic) chromium-aluminium-manganese spinels with an average of $46 \mathrm{wt} \%$ chromium oxide (shown in Fig. 4d \& f), and a few residual chromite mineral particles $\left(\mathrm{FeCr}_{2} \mathrm{O}_{4}\right)$ (Fig. 4c, d \& f). In comparison to the spinels, residual chromite is higher in iron oxide (average $6 \mathrm{wt} \%$ and 16 $w t \%$ respectively) while the spinels are considerably higher in manganese oxide (average 22 wt\%). Other non-reducible compounds of the molten charge crystallised as elongated 
calcium plagioclase feldspars similar to anorthite, $\mathrm{CaAl}_{2} \mathrm{Si}_{2} \mathrm{O}_{8}$ (average $46 \mathrm{wt} \%$ silica; $32 \mathrm{wt} \%$ alumina and $18 \mathrm{wt} \%$ lime) (Fig. 4c \& e; Table 3).

Table 3. Average elemental compositions of spinels, residual chromite and anorthite crystals (results shown in $w t \%)$. Number of samples and analyses are shown as $(n=x)$

\begin{tabular}{lcccccccccccc} 
& $\mathrm{Na}_{2} \mathrm{O}$ & $\mathrm{MgO}$ & $\mathrm{Al}_{2} \mathrm{O}_{3}$ & $\mathrm{SiO}_{2}$ & $\mathrm{~K}_{2} \mathrm{O}$ & $\mathrm{CaO}$ & $\mathrm{TiO}_{2}$ & $\mathrm{~V}_{2} \mathrm{O}_{5}$ & $\mathrm{Cr}_{2} \mathrm{O}_{3}$ & $\mathrm{MnO}$ & $\mathrm{FeO}$ & $\mathrm{n}=\mathrm{x}$ \\
\hline Spinel & & 5.9 & 17.6 & $<2.1$ & & 0.7 & 1.1 & 1.3 & 45.7 & 21.6 & 5.5 & $7=50$ \\
Residual Chromite & & 10.9 & 23.3 & & & 0.3 & $<0.4$ & $<0.7$ & 46.6 & 3.9 & 15.5 & $3=8$ \\
Anorthite & 0.9 & $<1.3$ & 31.5 & 45.7 & 0.8 & 17.8 & $<0.7$ & & $<1.3$ & 1.5 & $<0.8$ & $10=34$ \\
$\begin{array}{l}\text { Spinel (STDV) } \\
\text { Residual Chromite }\end{array}$ & & 3.1 & 5.2 & 1.8 & & 0.6 & 0.8 & 0.4 & 5.9 & 4.2 & 2.8 & \\
$\begin{array}{l}\text { (STDV) } \\
\text { STDV }\end{array}$ & & 3.4 & 2.8 & & & 0.0 & 0.3 & 0.3 & 3.9 & 3.4 & 9.4 & \\
\end{tabular}

240

The abundance of rounded and sub-rounded metal prills in the slag fins demonstrates a molten state of the metal produced in the crucibles (Fig. 4). Overall 62 area analyses were conducted on iron prills within 15 slag fin samples (see online supplementary data). Well-preserved metal prills have iron (average $97 \mathrm{wt} \%$ ) as the main constituent, always alloyed with chromium (average $1.4 \mathrm{wt} \%$ ), phosphorus (up to an average of $2 \mathrm{wt} \%$ ) and sometimes manganese (<0.4 wt\%) (Table 4$)$.

Table 4. Average composition of slag fin metallic prills (Area analyses; Results shown in wt\%; $n=$ number of samples, $\mathrm{x}=$ number of analyses)

$\begin{array}{lllllllllll} & \mathrm{Si} & \mathrm{P} & \mathrm{Ca} & \mathrm{V} & \mathrm{Cr} & \mathrm{Mn} & \mathrm{Fe} & \mathrm{Ni} & \mathrm{n}=\mathrm{x} & \text { Info } \\ \text { Average } & <0.3 & 2.0 & <0.4 & <0.7 & 1.4 & <0.4 & 96.7 & <0.7 & 14=65 & \begin{array}{l}\text { Vanadium only detected } \\ \text { in one analysis }\end{array} \\ \text { STDV } & 0.0 & 2.1 & 0.3 & 0.0 & 1.7 & 0.2 & 2.4 & 0.2 & & \end{array}$

\subsection{Smithing slags and the bloom}

Palm-sized magnetic lumps with one concave surface were identified as smithing slags (Fig. 5a \& b; Fig. 6a). They are very iron rich (average 69 wt\% FeO) with areas of partly corroded metallic iron, primary wüstite and other slag minerals. An iron bloom fragment bearing hammering marks was also found at the site. This sample is a partially consolidated bloom with metallic iron, wüstite and a lime-rich (average 20 wt\% CaO) slag phase (Fig. 5c \& 255 d; Fig. 6 b).

The smithing slag contains low percentages of manganese oxide and magnesium oxide, but with quite high lime (17 wt\%) appearing as calcium alumino ferrite $\left(\mathrm{Ca}_{2}(\mathrm{Al}\right.$, $\mathrm{Fe})_{2} \mathrm{O}_{5}$ ), and larnite $\left(\mathrm{Ca}_{2} \mathrm{SiO}_{4}\right)$ (Fig. 5) (Table 5). The slag phase of the bloom also contains inclusions with composition similar to larnite $\left(\mathrm{Ca}_{2} \mathrm{SiO}_{4}\right)$ with an average $60 \%$ lime content.

260 Both the smithing slag samples and the bloom do not contain chromium or magnesium oxides, but sometimes phosphorus oxide is present (average $1 \mathrm{wt} \%$ ) in smithing slags (Table 6). The metallic iron phase of both the bloom and smithing slags is ferritic (Fig. 6b), and 
devoid of chromium.

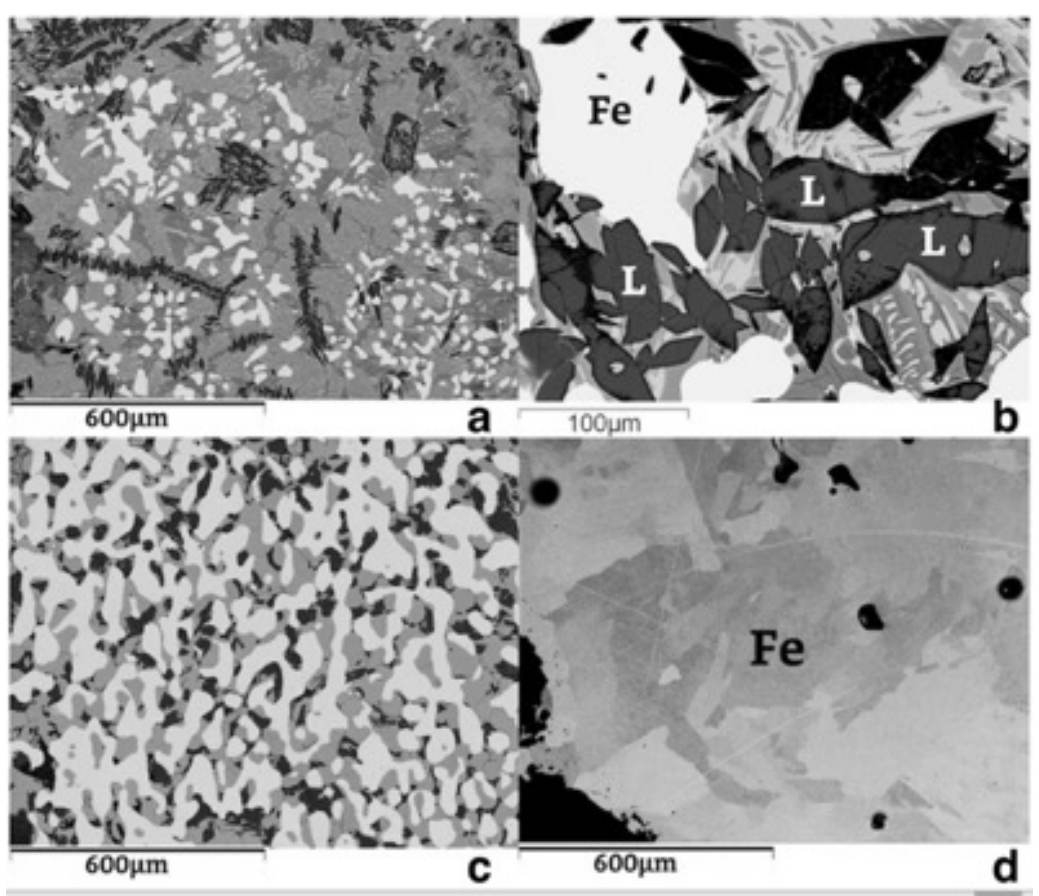

Figure 5, SEM-BSE images of smithing slag (a and $\mathbf{b})$, and bloom sample (c \& d). Image a. shows an area of the smithing slag with abundant iron oxide (grey) and metallic iron (white), with slag inclusions (larnite) in dark grey. The image $\mathbf{b}$. shows the crystal shape of larnite, the black spots are the voids created after the larnite crystals were removed during the polishing process. White phase is metallic iron and grey phases is iron oxide. The bloom sample exhibits higher metallic iron phase, as apparent in image c. in white. And the grey phase is iron oxide (wüstite). Some slag inclusions are visible as black-ish. Image d. shows a large metallic iron phase in the bloom. The ferrite grains are visible without etching. The images c \& d both show 600-micron areas of the bloom; but one has a 1:1 ratio of metallic iron to iron oxide, and the other is occupied by metallic iron.

Table 5. Chemical composition of 4 different smithing slag samples (SEM-EDS data in wt\%, data normalised). Area analyses (50x-100x and 200x) are taken from areas of dominant slag phase, avoiding metallic iron.

$\begin{array}{lccccccccc}\text { Samples } & \mathrm{MgO} & \mathrm{Al}_{2} \mathrm{O}_{3} & \mathrm{SiO}_{2} & \mathrm{SO}_{3} & \mathrm{P}_{2} \mathrm{O}_{5} & \mathrm{~K}_{2} \mathrm{O} & \mathrm{CaO} & \mathrm{MnO} & \mathrm{FeO} \\ \text { S3 } & 1.6 & 0.8 & 5.9 & 1.0 & & & 16.1 & 0.9 & 73.8 \\ & 0.4 & 0.8 & 7.4 & 0.5 & & & 16.8 & & 74.1 \\ \text { SS49 } & 2.6 & 3.5 & 7.8 & & & & 21.0 & 0.4 & 64.8 \\ & 2.2 & 3.0 & 16.2 & & & & 18.7 & & 59.9 \\ & 1.7 & 1.5 & 17.4 & & 2.2 & & 9.9 & 67.3 \\ & 1.3 & 1.6 & 13.8 & & 1.1 & 0.3 & 24.6 & 57.3 \\ & 1.7 & 1.3 & 11.8 & & 2.0 & 0.2 & 4.8 & & 78.2 \\ & 0.6 & 0.8 & 4.3 & & & & 23.0 & & 71.4 \\ \text { S5 } & 0.9 & 0.6 & 4.8 & & & & 22.1 & & 71.6 \\ & 0.6 & 1.4 & 9.9 & 0.6 & & & 11.2 & 2.1 & 74.2 \\ \text { S2 } & & 1.2 & 11.7 & & & & 23.4 & 1.6 & 62.1 \\ & & & & & & & & \end{array}$




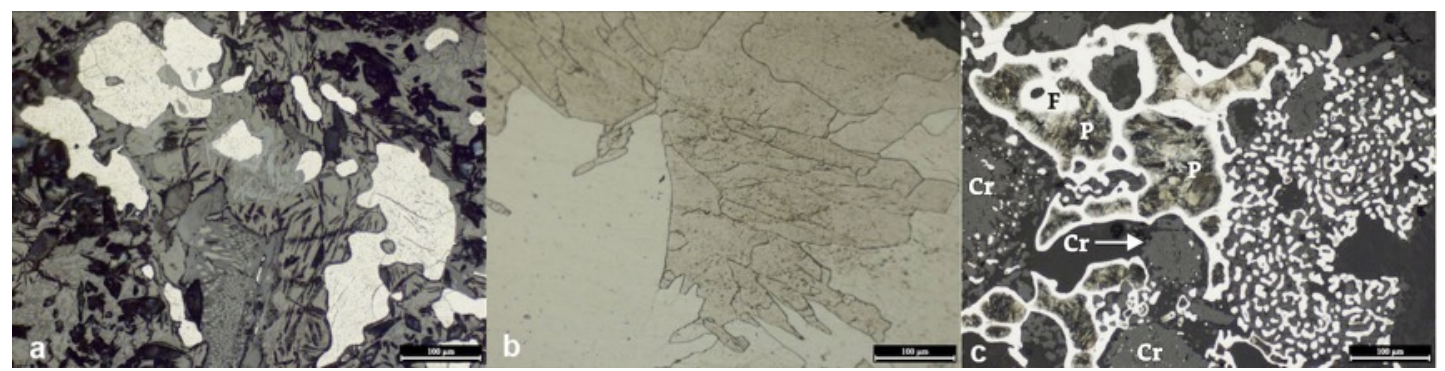

Figure 6. Optical microscope images of ecthed metallic phases in a smithing slag, a bloom and a slag fin samples: $\mathbf{a}$. etched smithing slag, shows ferritic iron in iron oxide and slag inclusion matrix; $\mathbf{b}$. shows the ferrite grains of the bloom's metallic phase; and c. shows pearlitic phases (marked as P) of metallic prills (ferrite grains marked as F) in Chahak slag fin, which have started to decarburise after the production, the important feature of this image is the residual chromite grains that are visible in light grey(marked as $\mathrm{Cr}$ )

Table 6. Chemical compositions of two samples taken from the bloom, excluding metallic iron phase from the analyses (area analyses of 50x to 300x, results shown in wt\%, data normalised). Note that the analyses include only the slag phases such as larnite and wüstite.

\begin{tabular}{ccccccccc} 
& $\mathrm{MgO}$ & $\mathrm{Al}_{2} \mathrm{O}_{3}$ & $\mathrm{SiO}_{2}$ & $\mathrm{P}_{2} \mathrm{O}_{5}$ & $\mathrm{SO}_{3}$ & $\mathrm{~K}_{2} \mathrm{O}$ & $\mathrm{CaO}$ & $\mathrm{FeO}$ \\
\hline Sample 1 & 2.1 & & 3.0 & 0.3 & & & 6.5 & 88.1 \\
& 3.5 & & 12.8 & 4.0 & 0.4 & 0.2 & 24.2 & 54.8 \\
& 1.5 & & 4.1 & 0.7 & & & 7.5 & 86.2 \\
& 2.5 & & 5.2 & 1.0 & & & 9.3 & 81.9 \\
Sample 2 & 1.0 & 0.7 & 8.7 & 0.5 & & & 17.0 & 72.1 \\
& 1.0 & 1.5 & 6.9 & & 1.1 & & 23.0 & 66.4 \\
& 2.3 & 1.1 & 9.6 & 0.8 & 0.9 & 0.2 & 23.4 & 61.8 \\
& 1.5 & 1.5 & 7.5 & 0.5 & 1.0 & & 25.3 & 62.8 \\
& 3.8 & 1.4 & 11.2 & 2.1 & 1.1 & 0.3 & 29.8 & 50.3 \\
& 1.6 & 2.7 & 1.6 & & 2.0 & & 29.3 & 62.8 \\
Average & 2.1 & 1.5 & 7.1 & 1.2 & 1.1 & 0.2 & 19.5 & 68.7
\end{tabular}

\section{Discussion}

\subsection{Crucible production}

Chahak crucibles exhibit production features such as coiling of the bottom half of the crucible (based on typical step-like factures) (Rye 2002, 67) and textile fabric impressions on the inner crucible wall (Fig. 7a \& b) that correspond to possible drawing of the wet clay towards the top. Prior interpretations of a similar feature in Central Asian crucible steel making crucibles (Rehren and Papachristou 2003, 400; Rehren and Papakhristu 2000) suggested that the crucibles were formed by using a textile mould filled with sand. However, we argue that such mould would not be stable enough to ensure the standardised shape seen in both the Central Asian and Chahak crucibles. A wooden mould covered with textile to introduce a barrier between the mould and clay and provide support to the clay 
seems more stable, and able to maintain the level of standardisation seen in the archaeological record (Fig. 8).

A practical example of such wooden moulds can be seen in an ethnographic report of crucible production for lead crucible smelting in China (Zhou et al 2014, 205); this example may not be metallurgically relevant to the crucible steel making tradition in Persia, but it does demonstrate the practicality of such method from a potters' perspective. These pre-formed crucibles would then have been fired to ensure stability to receive the charge, including several kilograms of iron fragments and other ingredients. The Chahak crucible lids are made of the same clay, but based on their inner surface features (indentations suggesting wet clay touched the contents), they were added as a lump of unfired clay pushed on top of the charged crucible before firing (for a reconstruction of Chahak crucibles see Fig. 9).

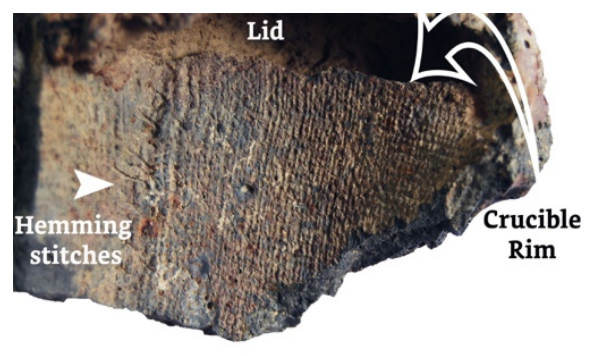

$\mathbf{a}$
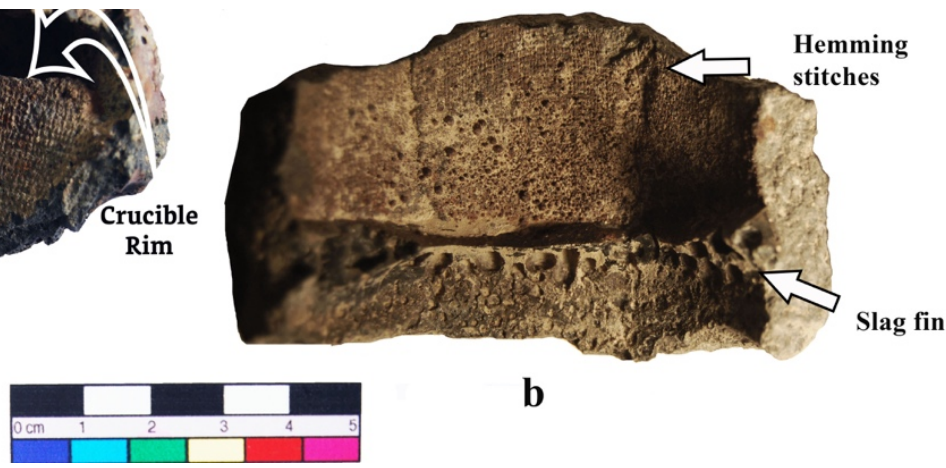

b

Figure 7. Crucible wall fragments featuring: a. an upper crucible fragment with lid attached to it, with visible textile impressions and hemming stitches of the textile template; $\mathbf{b}$. a middle crucible fragment featuring slag fin and the textile impressions on the upper part with a visible hemming stich mark; the slag is representative of the majority of Chahak slag fins, being very thin. 

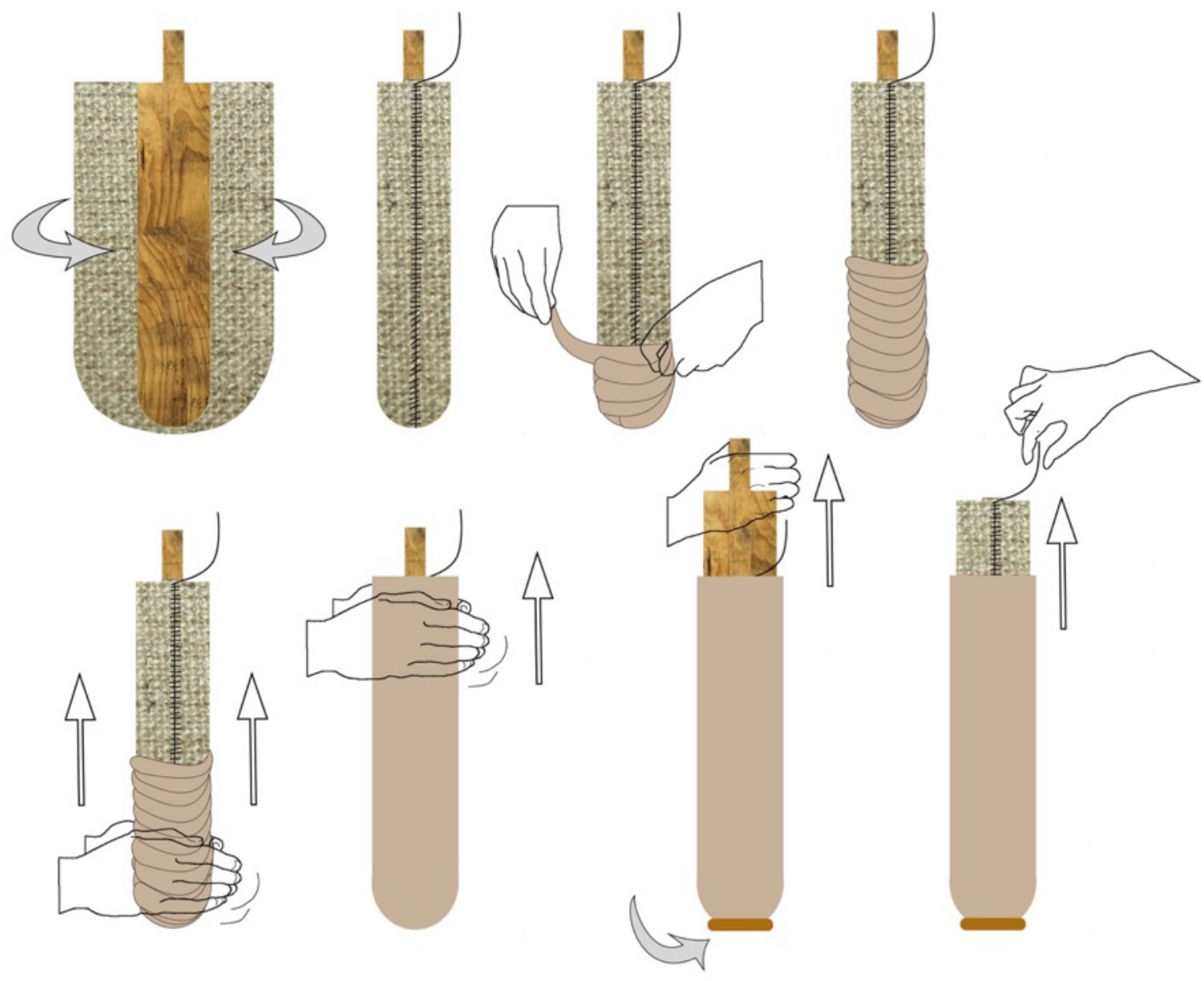


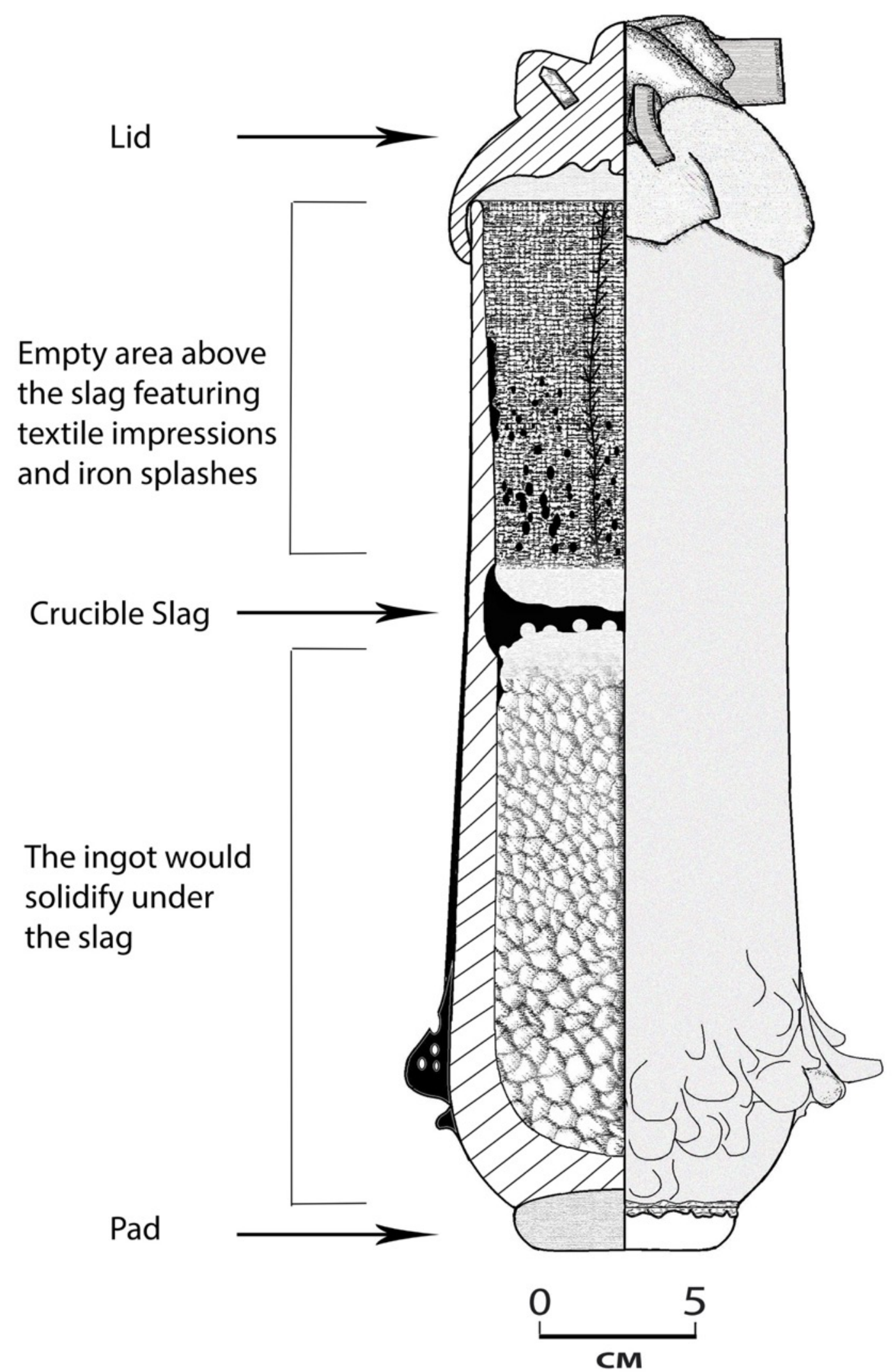

Figure 9. Reconstruction of Chahak crucibles based on archaeological fragments (modified from Alipour and Rehren 2014) 


\subsection{Technical ceramics}

Chahak crucibles contain considerable amount of iron. Iron oxide is detrimental to the refractoriness of ceramic, acting as a flux to the main silica content; however, in the Chahak crucibles and lids it has been completely reduced to finely dispersed metal prills in the ceramic matrix, therefore removing the deleterious effect of iron oxide (Freestone and

325 Tite 1986, 54; Bayley and Rehren 2007, 47; Martinón-Torres and Rehren 2014, 114) (as seen in Fig. 2a \& b). However, in Chahak's case, there is no evidence of an organic temper. Therefore, this transformation supports the hypothesis that crucibles were sufficiently porous for carbon monoxide (CO) produced inside the crucibles to flow through the crucible walls.

330 However, the iron content of the fuel ash glaze on the exterior of the crucibles has also reduced to iron prills (Alipour 2017, 239), which may indicate a reducing condition of the furnace, but other evidence does not support this hypothesis: the iron within the pads' matrix has not reduced to metal, this may be due a lower temperature at the lower part of the crucibles, or simply signify an oxidising atmosphere of the furnace. The crucibles were

335 possibly pushed into the furnace bed and the pads covered by gravel. There is no direct link between the pads and the reducing atmosphere within the crucibles.

The tuyères and the domestic pottery have a similar composition to the crucible pads, being very different from the crucible wall components. This contrast suggests the selection of a particular type of clay specifically for crucible manufacture, reflecting the craftsmen's awareness of different clay qualities, properties and behaviour. At this stage, it is unknown whether the domestic pottery has been made from local clay, and whether the crucible clay was obtained from a non-local source. However, it is likely that the metallurgists manufactured the crucibles in situ, i.e. within the Chahak crucible steel making workshops; the physical evidence suggests that the fully charged crucibles were sealed with

345 a lump of clay identical to that of the crucibles' bodies, suggesting its availability in the workshops.

The chemical composition of the Chahak crucible walls, pads and the tuyères and domestic pottery were plotted in the $\mathrm{Al}_{2} \mathrm{O}_{3}-\mathrm{CaO}-\mathrm{SiO}_{2}$ ternary diagram based on Freestone and Tite's $(1986,57)$ method of assessing crucible refractoriness (Fig. 10). Some fluxing oxides such as $\mathrm{Na}_{2} \mathrm{O}, \mathrm{MgO}, \mathrm{K}_{2} \mathrm{O}$ and $\mathrm{FeO}$ were added to the $\mathrm{CaO}$ vector of the diagram as these elements behave similarly to $\mathrm{CaO}$ in decreasing the melting point of the ceramics. However, for the crucible composition, $\mathrm{FeO}$ was omitted as the iron content of the ceramic has been reduced to iron metal, and therefore does not influence the ceramic composition and behaviour any more. 


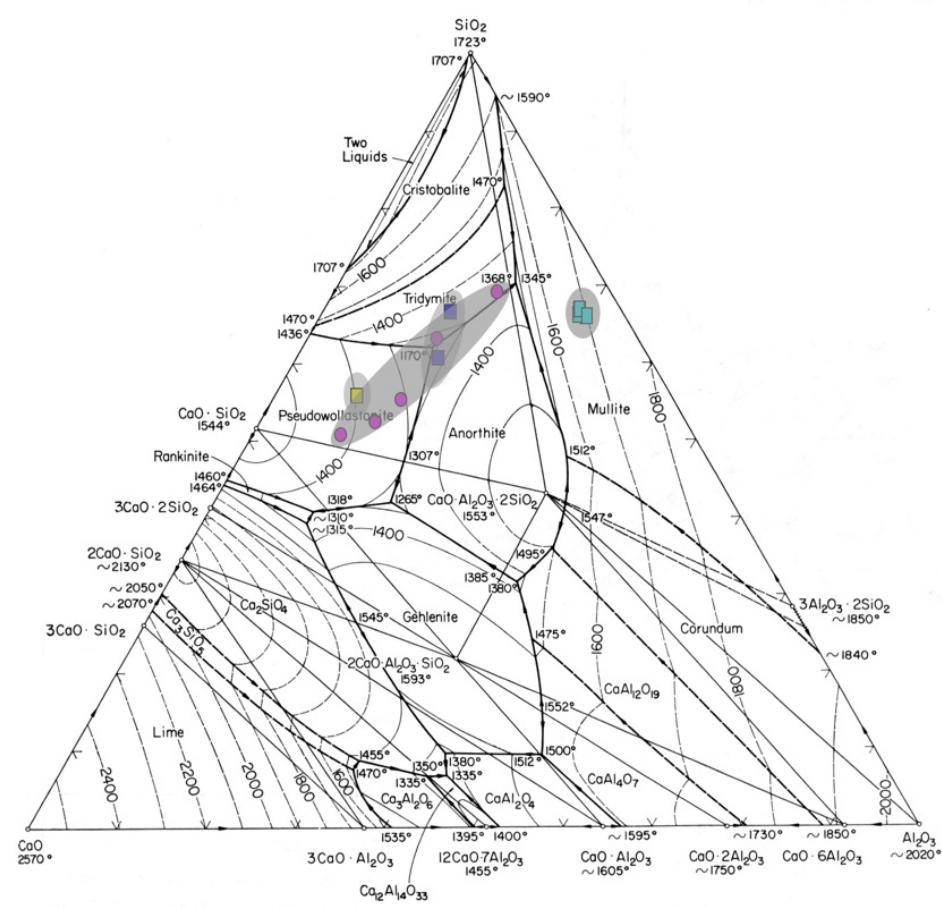

Figure 10. Chahak ceramics: Crucibles (bright blue rectangles on the right side of the diagram), crucible pad (yellow rectangle on the left), tuyères (blue rectangles) and domestic pottery (pink circles)

The crucible composition plot in the mullite zone $\left(1700^{\circ} \mathrm{C}\right)$, implying that crucibles could withstand temperatures higher than typical historical refractory ceramics (historical refractories tolerate at least $1200^{\circ} \mathrm{C}$ as stated by Freestone 1989), well above the temperature required for the crucible steel process of around $1400^{\circ} \mathrm{C}$ (Craddock 1995, 276; Rehren and Papakhristu 2000, 64). On the other hand, the tuyères (within the $1170^{\circ} \mathrm{C}$ and $1300^{\circ} \mathrm{C}$ zones), pad $\left(1400^{\circ} \mathrm{C}\right.$ ) and domestic pottery (within the $1170^{\circ} \mathrm{C}$ to $1450^{\circ} \mathrm{C}$ zones) group towards the calcium and flux-rich corner of the phase diagram.

\subsection{Slags, iron prills and the bloom}

The slag consists of four major oxides present at concentrations above c. $10 \mathrm{wt} \%$ (silica, alumina, lime, manganese oxide), in addition to several minor oxides with concentrations between 0.5 and 5 wt\% (soda, magnesia potash, titanium oxide, chromium oxide, iron oxide) (see Table 2). The lime in the slag fin indicates the addition of a lime rich

370 raw material. The high amount of manganese oxide in the slag fin indicates deliberate addition of a manganese rich flux (such as the common pyrolusite). Manganese oxide is mentioned in contemporary manuscripts as a component of the crucible charge, and facilitates carbon absorption during steel formation (Charlton 2007, 106; Iles 2014, 423; Rehren et al. 2007, 212; Truffaut 2014). One of the main functions of manganese oxide in

375 Chahak slag fins is to substitute the iron content of the slag. Consequently, the iron oxide content of slag fins is typically lower than $2 \mathrm{wt} \%$, compared to around $50 \mathrm{wt} \%$ iron oxide in most pre-industrial iron smelting slags (Rehren et al. 2007, 212). Chromite is not found in 
Chahak crucible fabric (see Table 1) or any of the finds from the smithing workshop (see section 2.3, Table 5), hence making an external source of chromium very likely.

According to the Ellingham diagram (Ellingham 1944, 127) (Fig. 11), reduction of manganese requires more strongly reducing conditions than chromium. Therefore, more manganese oxide has remained in the slag in comparison to chromium oxide; and consequently, chromium is reduced in higher rates than manganese. The chromium content fluctuates within and among iron prills (0.2-12 wt\%), reflecting the chromium content of either the cementite (with higher concentration of chromium) (Ando and Krauss 1981), or the ferrite (typically lower in chromium). Etching the prills with nital $2 \mathrm{wt} \%$ (Fig. 12a-c) reveals mainly pearlitic structure and few ferrite grains, which suggests carbon in the order of one per cent by weight. We would need more samples with iron prills large enough for etching to have a better understanding of a hypothetical carbon content of Chahak crucible steel.

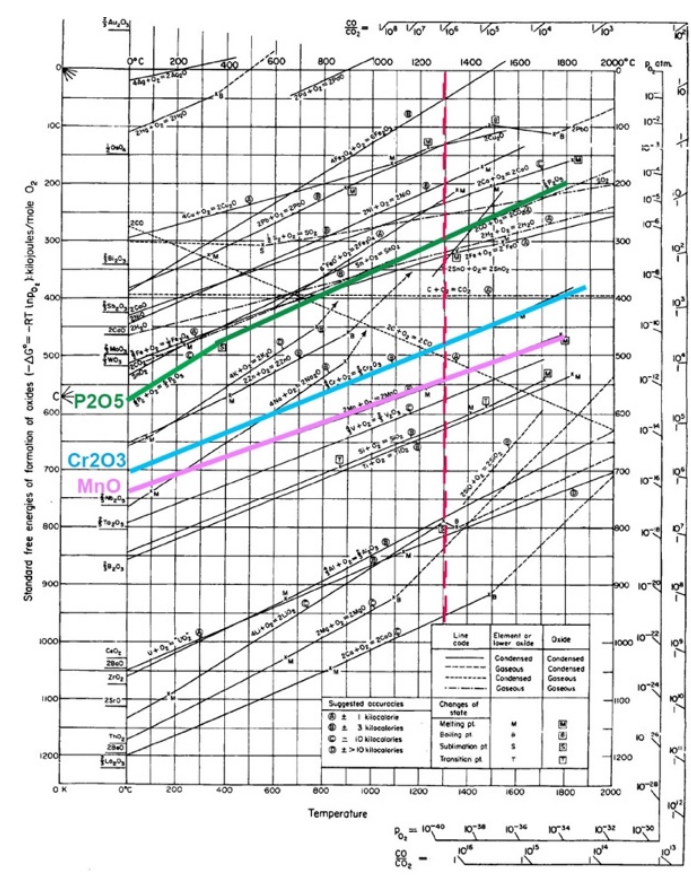

Figure 11. "Free energy diagram of the metal-metal oxide system, highlighting $\mathrm{Mn}, \mathrm{Cr}$ and $\mathrm{P}$ as the alloying components of Chahak crucible steel ingot (Craddock 1995, 190). The CO/CO2 ratio and minimum partial pressure of oxygen can be estimated using the tentative temperature highlighted in red cross-hatched

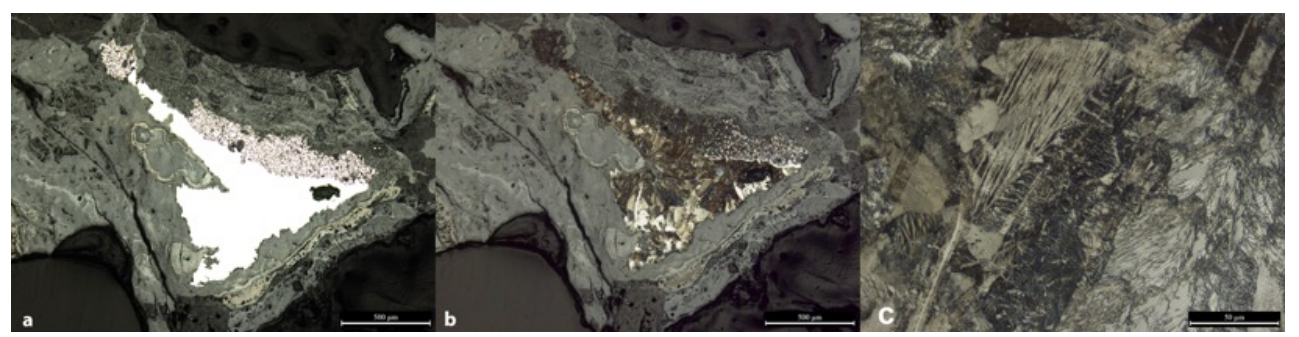

Figure 12. Optical Microscope images of metallic phase in slag fin: $\mathbf{a}$. before etching; $\mathbf{b}$. after etching, showing the pearlitic structure of the metallic phase; $\mathbf{c}$. close up of the etched region.

To estimate the operating temperatures of Chahak crucible steel production, the 
components of Chahak slag. But since the bulk slag composition contains more than three elements, other oxides were added to the element to which they behave similarly in the slag. To do this, the magnesium oxide and iron oxide contents were added to the lime vector of the $\mathrm{CaO}-\mathrm{SiO}_{2}-\mathrm{Al}_{2} \mathrm{O}_{3}$, and to the manganese vector of the $\mathrm{MnO}-\mathrm{SiO}_{2}-\mathrm{Al}_{2} \mathrm{O}_{3}$ ternary phase diagram, since these two oxides behave similarly to lime and manganese oxide. Additionally, chromium and titanium oxide were added to the alumina vector of the phase diagram, as they behave similarly to alumina. Afterwards, the elements for each phase diagram were recalculated and normalised to $100 \%$ before plotting them into the diagrams. The slag compositions fall into the low-melting area of the diagrams, with nominal liquidus temperatures between $1265^{\circ} \mathrm{C}$ in the $\mathrm{CaO}-\mathrm{SiO}_{2}-\mathrm{Al}_{2} \mathrm{O}_{3}$ phase diagram, and c. $1350{ }^{\circ} \mathrm{C}$, and above $1200{ }^{\circ} \mathrm{C}$ in the $\mathrm{MnO}-\mathrm{SiO}_{2}-\mathrm{Al}_{2} \mathrm{O}_{3}$ phase diagram (Fig. 13a \& b). However, due to the complex multi-component nature of the slag, the actual operating temperatures might well have been lower, hence any data driven from plotting the slag composition on ternary diagrams provides only an approximate operating temperature.
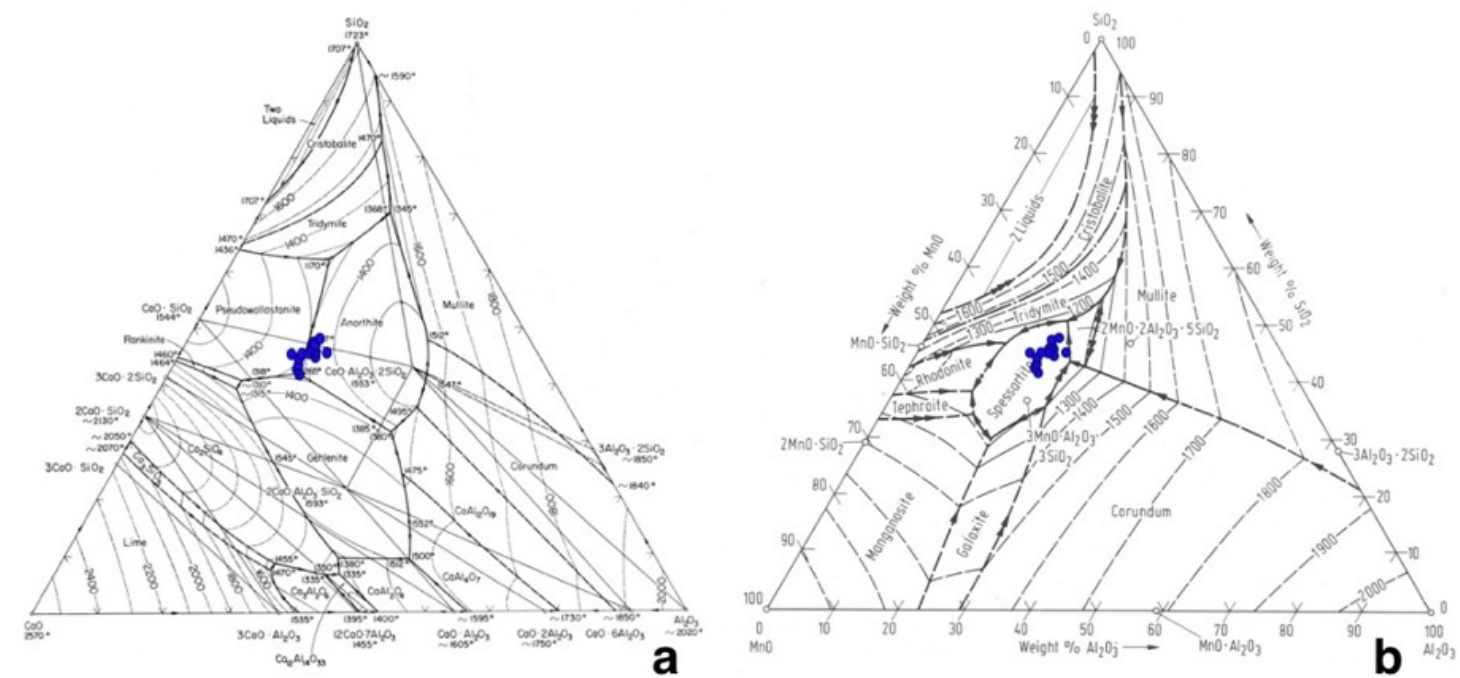

Figure 13. Chahak slag fin chemical composition plotted on $\mathrm{CaO}-\mathrm{SiO} 2-\mathrm{Al}_{2} \mathrm{O} 3$ ternary diagram (a), and $\mathrm{MnO}-\mathrm{SiO}_{2}-\mathrm{Al}_{2} \mathrm{O}_{3}$ ternary diagram (b). See text for data treatment.

The absence of chromium in the smithing slags and the bloom suggest that the chromium did not enter as an impurity with iron ore, and smithing slags formed during the consolidating of fresh bloomery iron, and not as a result of crucible steel forging. Some residual chromite is visible in some slag fins (as seen in Fig. 6c). The exceptionally high lime content of the smithing slag and the bloom's slag inclusions correspond well with the elevated amount of calcium oxide (average $16.5 \mathrm{wt} \% \mathrm{CaO}$ ) in the crucible slag. The very low concentration of silica, of around 5 to $15 \mathrm{wt} \%$ and the resulting non-glassy texture of the slag phase are unlike blast furnace slag (Herrmann et al. 1997, 13; Feuerbach et al. 1997; Simpson 2001). Additionally, any smithing slag is unlikely to be similar to blast furnace slag since cast iron is not smithed. Therefore, cast iron is unlikely to have been part of the Chahak crucible feedstock as would be expected in the co-fusion method. 


\subsection{Tentative ingot and slag fin weight}

$430 \quad$ The volume of the crucible is calculated based on the average internal radius $(r)$ of 3.4 $\mathrm{cm}$ and the estimated minimum and maximum inner height of the crucibles $(25 \mathrm{~cm}$ and 30 $\mathrm{cm})$. Using these figures, the entire internal volume of a Chahak crucible would be around one litre $\left(907 \mathrm{~cm}^{3}\right.$ to $\left.1089 \mathrm{~cm}^{3}\right)$. Based on the surviving samples, the height from the crucible base to the slag line, which marks the length of the ingot, is between 11 to $16 \mathrm{~cm}$.

435 Therefore, the ingot volume is calculated around half a litre $\left(340\right.$ to $\left.580 \mathrm{~cm}^{3}\right)$, and the weight of the ingots would be around three to five kilograms (using a steel density of 8.0 $\left.\mathrm{g} / \mathrm{cm}^{3}\right)$. In support of this estimate, Biruni's recipe states that 5 ratl of soft iron is added as crucible charge; taking the $720 \mathrm{~g}$ for one ratl (Dehkhoda 1993(III), 3131; (XIII), 10684) gives around four kilograms which is quite close to a typical Chahak iron input.

440 Since the crucibles are broken, no complete slag fin was found. The retrieved pieces are around one centimetre thick at the point of contact with the interior crucible wall (Fig. 4b); while the middle section of the slag fins is missing. From extant fragments, the volume of the crucible slag can be estimated at c. $36 \mathrm{~cm}^{3}$, weighing c.90 grams (using a slag specific density of $2.5 \mathrm{~g} / \mathrm{cm}^{3}$ ). However, as the thicknesses of the slag fins tapers towards the centre, a more conservative tentative estimate of $50 \mathrm{~g}$ is more reasonable for the slag cakes at Chahak.

\subsection{Estimated ingot components and characteristics}

Based on the tentative four kilograms Chahak ingot, and the composition of the slag fin iron prills, we can reconstruct the initial charge. The three main alloying components are carbon, phosphorus and chromium, all in the order of 1 to 2 wt\% (Table 4). Manganese was found sporadically in the prills, but it largely remained in the oxide slag. These four elements have been added to the charge deliberately; while vanadium and nickel represent the impurities that come along with the main ingredients, such as iron source, and appear only sporadically in low concentrations. However, despite the irregular appearance, when present, these alloying elements have an important impact on the crucible steel quality and resulting pattern.

Based on Verhoeven et al. $(1998,63)$, the micro-segregation of carbide forming elements in hypereutectoid steels promote the band structure of the famous crucible steel patterns, three of which are present in Chahak slag fins and iron prills ( $\mathrm{Cr}, \mathrm{Mn}$ and $\mathrm{V}$ ).

460 Vanadium, even in very small amount (as low as 40 parts per million by weight, ppmw) is effective in creating the carbide bands. Elsewhere, Verhoeven et al. (1996) state that addition of vanadium and chromium as little as $0.02 \mathrm{wt} \%$ would promote the coarsening of the cementite particles and result in appearance of cementite bands as a result of meticulous heat treatment and forging. If such low amounts of vanadium present in an iron ore encouraged the craftsmen to select such kind of iron source, it is highly likely that an 
addition of a mineral with such high concentrations of chromium oxide could not have been accidental. It is clear that segregation of $1 \mathrm{wt} \%$ chromium in the ingot is too high to be considered as an impurity. This amount of a carbide forming element is high enough to create a noticeable change in the quality of the crucible steel.

To obtain $2 \mathrm{wt} \%$ phosphorus in a $4 \mathrm{~kg}$ metal ingot, the crucible charge would have required $80 \mathrm{~g}$ elemental phosphorus, or $184 \mathrm{~g}$ of phosphorus oxide $\left(\mathrm{P}_{2} \mathrm{O}_{5}\right)$. Common sources of phosphorus such as bone ash or apatite would have contributed similar amounts of lime to the system, exceeding the total weight of the slag fin. Phosphorus was therefore likely introduced into the crucible as part of the iron charge. As an alloying element in steel, 475 phosphorus would simultaneously reduce the melting point and increase the strength and work hardenability of the steel. However, it also reduces the toughness and renders the metal fragile and 'cold short' (Stewart et al. 2000, 275; Iles 2014, 439). Additionally, such high amounts of phosphorus would have made the ingot hot-short and impossible to forge; however, Verhoeven et al. (1996) proposed a rim heat treatment technique that would have 480 made it possible to forge such ingots. As a result, phosphorus is mostly considered to be detrimental to steel structure (Rostoker and Bronson 1990, 125; Gladman 1997, 37; Morris $2008,1022)$. In this context, historical accounts highlight Chahak blades as brittle, and losing their value consequently (Alipour and Rehren 2014, 241).

Assuming a bulk chromium content of around $1.4 \mathrm{wt} \%$ in the metal, the $4 \mathrm{~kg}$-ingot would hold c. $56 \mathrm{~g}$ metallic chromium. Pure chromite contains nearly $68 \mathrm{wt} \% \mathrm{Cr}_{2} \mathrm{O}_{3}$; however, natural chromite mineral $\left(\mathrm{FeCr}_{2} \mathrm{O}_{4}\right)$ is typically composed of 50 to $60 \mathrm{wt} \%$ chromium oxide, or c. 35 to $40 \mathrm{wt} \%$ elemental chromium. Thus, about 125 to $150 \mathrm{~g}$ of chromite mineral would have been required in the system, allowing also for some chromite to enter into the slag. It is extremely unlikely that this much chromite (or any other

490 Chromium-rich mineral) would have entered the crucible charge by accident or as a regular impurity in any of the other ingredients of the charge. The identification of this deliberate addition of chromite as part of the Chahak crucible steel industry is central to our argument.

The concentration of chromium is very low in early iron and steel artefacts, and usually restricted to less than one hundred parts per million (e.g., Rehder 1989 reports 495 chromium concentrations in Luristan iron swords of around $50 \mathrm{ppm}$ ). The levels detected here can therefore act as specific identifier for the Chahak process and help provenance relevant artefacts. Until this study, percentage-level chromium has widely been known only as an element in modern steel to either increase strength and hardenability (0.5-2 wt\%), or corrosion resistance (4-18 wt\%) of the metal (Degarmo et al 2007, 144; Gregory 1932, 500 120,121). Accordingly, the chromium present in Chahak crucible steel ingots would have primarily affected the mechanical properties of the steel. The use of chromium in other industries, prior to its isolation as an element in the late $18^{\text {th }}$ century, has rarely been reported. The alleged use of chromium as a corrosion inhibitor on bronze weapons in Qin 
period China has recently been shown to be a contamination from chromium-containing lacquer rather than intentional (Martinón-Torres et al. 2019).

However, the mineral chromite was used as a black colourant on Islamic ceramics, including Iranian Mina'i ware of the late $12^{\text {th }}$ C. CE (e.g., Mason et al. 2001, 191-8; Freestone $2002,251)$. Therefore, other contemporary industries could have shared the usage of this regionally abundant mineral, as witnessed in Chahak. This finding becomes of particular 510 importance in view of the detection of chromium in a Persian flint-striker of the $12^{\text {th }}-13^{\text {th }} \mathrm{c}$. CE Seljuq period (contemporary to Chahak's active production); this object contains up to $3.7 \mathrm{wt} \%$ chromium and $0.3 \mathrm{wt} \%$ manganese in its cementite composition (Allan and Gilmour $2000,437,512)$. Since the concentration of the above elements is analysed in the cementite composition, the overall chromium and manganese of the metal would be lower.

515 The pearlitic structure of the metal prills in the Chahak slag fin, with no cementite boundaries, suggests a carbon content of around $0.8 \mathrm{wt} \%$. The most immediate influence of carbon absorption is the reduction of the melting point of the iron (Verhoeven 2007, 9). If kept below $2 \mathrm{wt} \%$, carbon also increases the mechanical strength of the steel (Rostoker and Bronson 1990, 12- 9). Based on the estimated carbon content (0.8 wt\%), an amount of 520 around $70 \mathrm{~g}$ carbonaceous matter (containing $50 \mathrm{wt} \%$ carbon), or $35 \mathrm{~g}$ charcoal would have been needed for this process.

The last element to be mentioned in Chahak crucible steel is manganese. Manganese decreases ferrite grain size and assists refining pearlite's lamellar structure, which improves the characteristic damask pattern. These convoluted patterns are mainly related to the 525 pearlitic microstructure of the crucible steel ingots, and the smiths' meticulous forging technique (Verhoeven. et al. 1998, 59). More importantly, manganese increases the toughness and strength of the steel (Gladman 1997, 275; Truffaut 2014). For a typical Chahak ingot with 0.4 wt\% of manganese, $25 \mathrm{~g}$ of pyrolusite would have been needed (Table 7), with additional amounts required to provide for the significant manganese oxide content 530 in the slag (12 wt\%). It is noteworthy that manganese oxide has been sporadically present in the smithing slags (primary smithing slags), and in very small quantities; hence, the possible slag trapped in the iron feedstock could not have provided such high amounts of manganese oxide in the slag.

Table 7. Ingot components and tentative corresponsive minerals and organic matter

$\begin{array}{lcccc}\text { Elements } & \begin{array}{c}\text { Estimated ingot } \\ \text { components wt\% }\end{array} & \begin{array}{c}\text { Bulk amount in a } 4 \\ \text { kg ingot (g) }\end{array} & \begin{array}{c}\text { Source } \\ \text { (g) }\end{array} \\ \mathrm{P} & 2.0 & 80 & \text { unknown: bloom? } & \\ \mathrm{Cr} & 1.4 & 56 & \text { Chromite } & 125-150 \\ \mathrm{C} & 0.8 & 32 & \text { Carbon } & 35-70(100) \\ \mathrm{Mn} & 0.4 & 16 & \text { Pyrolusite } & 25 \\ \mathrm{Fe} & 96.7 & 3,816 & \text { Iron bloom } & 4,000\end{array}$




\subsection{Significance of Biruni's recipe}

Biruni records four kilograms of horseshoes and their nails as the soft iron source. The weight mentioned is comparable to Chahak's tentative ingot weight. We interpret this as bloomery iron, which could be forged into smaller nail-like iron rods to increase the reaction surface and to fit into the tall and narrow crucibles. This is in line with the

540 abundance of smithing slags from Chahak. For us, the most important component of Biruni's recipe is $32 \mathrm{~g}$ rusakhtaj ('the burnt'), and based on its literal meaning we propose here to be identified as chromite sand.

Biruni's recipe includes another $32 \mathrm{~g}$ of magnesia, an ingredient recurrently mentioned in historical crucible steel-making recipes. The assumption is that this refers to 545 manganese oxide rather than magnesium oxide, and its source is the common mineral pyrolusite $\left(\mathrm{MnO}_{2}\right)$, whose appearance is consistent with the description of the magnesia known as the "black substance" used in glass making (for whitening glass) and ceramic industry (for painting vessels) (Freestone et al. 1985). The analytical results of the Chahak slag fin also estimate an addition of $30 \mathrm{~g}$ of pyrolusite. The meaning of marqshisha talaie or

550 golden marcasite (iron pyrite) in the recipe is not immediately clear, as no sulfur-rich phase has been identified in the archaeological remains, and adding sulfur to crucible steel would negatively impact its performance. Biruni's addition of edible salt to the charge is consistent with the elevation of soda in the composition of the inner surface of the Chahak crucible lids (see Alipour 2017), and most likely served as a flux to facilitate the formation of a liquid slag

555 phase early on in the process. Edible salt as an ingredient has also been observed in other historical industries, such as zinc smelting in late medieval India (e.g. a zinc distillation recipe written in Rasaratnasamuccaya in $14^{\text {th }}$ C. CE India) (Craddock et al. 1983, 215). Biruni further mentions oyster shell, which is mostly calcium carbonate (Hamester et al. 2012, 205). However, the analyses of the slag fin have already demonstrated that the lime-rich iron 560 bloom's slag inclusions would have provided the necessary amount of lime (17 wt\%) in the slag fin, making an addition of a calcareous material unnecessary.

The type of carbonaceous matter used for the transformation of iron to steel is mentioned in historical recipes. Biruni lists the addition of $64 \mathrm{~g}$ of organic material (contributing c. $30 \mathrm{~g}$ carbon), in form of pomegranate rinds and myrobalans (halila),

565 sufficient to produce an ingot of $4 \mathrm{~kg}$ with $0.8 \mathrm{wt} \%$ carbon. Pomegranate is native of Iran and carries spiritual and mystical values in ancient Persian culture as the fruit of heaven and symbol of fertility. Aside from its important technical role, pomegranate probably dignified and guaranteed a successful production of crucible steel. Myrobalans, on the other hand, is a prune-like fruit of Asiatic origin, and known as an ingredient in historical Indian recipes of

570 zinc production (Freestone et al. 1985). Similar to the silica present in the slag fin but not mentioned as an ingredient in Biruni, phosphorus is not listed as a recipe ingredient. It is also not detected in the slag fin, but reduced into the slag fin's metal prills where it was 
found in high amounts ( $2 \mathrm{wt} \%$ ). It is therefore possible that phosphorus was not a desired ingredient, and probably entered the system as an impurity (Principe 1987, 22).

Two other historical recipes of crucible steel production, by Khayyam ( $11^{\text {th }} \mathrm{C}$. CE) and Al-Tarsusi (12 ${ }^{\text {th }}$ C. CE) (Alipour and Rehren 2014; Alipour 2017), report carburisation of soft iron mostly with plant and fruit matter. Magnesia is also listed in the recipes, while Khayyam also lists the addition of a calcareous matter. Therefore, crucible steel making of the $10^{\text {th }}$ to $12^{\text {th }} \mathrm{C}$. CE is dominated by carburising processes with many ingredients in common, but the 580 addition of rusakhtaj (chromite) is exclusive to Biruni's recipe.

\subsection{Summary}

The steel making technology in Chahak is peculiar due to the presence of chromium and phosphorus in the slag fin iron prills, which indicate a tentative Chahak ingot composition. Additionally, the chromium oxide content of the slag fins, and the unusually

585 high lime and subsequent low silica content of the smithing slags and the bloom's slag inclusions are exclusive to the Chahak crucible steel tradition. The absence of chromium oxide in the smithing slag and the bloom indicates that they belong to the refining process of the bloom for the crucible charge. Furthermore, the sporadic presence of manganese oxide in the smithing slags is indicative of primary smithing slags, as manganese normally exits the system at the early stages of refining the bloom, and into the smithing slag.

The absence of phosphorus oxide in the slag fin provokes the question whether it has been added deliberately but had fully reduced into metal; or if it has already entered the system in metallic state as an impurity with the iron. The presence of phosphorus oxide in the bloom's slag inclusions (average $1.2 \mathrm{wt} \%$ ) may provide grounds for the assumption

595 that phosphorus alloyed with iron prior to entering the crucible, and remained reduced within the crucible and never joined the slag. However, the analyses of the five smithing slags shows that phosphorus oxide was present in only in one smithing slag (average $<0.7$ $w t \%)$. Hence it is not very clear whether this theory (that phosphorus comes into the crucible charge with the bloomery iron) is viable. On the other hand, phosphorus reduces to metal earlier than other alloying materials present in Chahak prills, such as chromium and manganese. Therefore, any added phosphorus compound could have been completely reduced to metal before the melt started to reduce the chromite.

Besides, chromium reduces earlier than manganese, and is always present in all of the iron prills analysed in the slag fins. Only if the amount of manganese present in the slag was high enough, it would have reduced into the metal; and as its reduction is harder than the reduction of phosphorus and chromium, the concentration of manganese oxide in the slag fin is always higher than the manganese reduced into the prills. Conversely, the chromium oxide content of the slag fin is always less than the chromium content of the prills. 

metal later than the above elements, hence their only very sporadic presence in the prills. The crucible slag fin has considerably higher amounts of silica than the bloom and smithing slags, while the calcium content remains relatively the same. A reason for that is that smithing slags and the bloom's slag inclusions have mostly iron oxide, which when reduced

615 to metal, almost pure lime remains in the slag. This amount of lime then needs additional silica to get back to the level that is seen in the slag. Basically, silica, alumina and in particular manganese oxide and other oxides replace iron oxide in the bloom's slag inclusion. On the other hand, the increase of silica in the slag fins, in comparison to the low silica in bloom's slag inclusions, indicates that it does not enter the melt system from the 620 iron input. Given that the crucibles would contribute only a very limited amount of silica (see the concave slag line on the crucible's interior in Fig. 1b), silica must have entered the charge with other ingredients. One possible way would be the addition of the chromium source as chromite sand (from a placer deposit) (Misra 2000, 238). Chromite sand naturally comes with high amounts of silica sand, and as its separation is laborious, it is very likely

625 that the specialists only collected the black sand (chromite sand) from the chromium rich deposits and added it to the charge, which provided both the chromite and silica necessary to facilitate the slag formation and feed the required amount of chromite. The addition of such source of chromite also is indicative of a very chromite rich geology. In fact, chromite deposits are abundant around Chahak (Hall 1981; Moore \& Jajab Zadeh 1993; Yaghubpur \& 630 Hassannejad, 2006; Alipour 2017, 358; Attarzadeh et al. 2017) (See online supplementary material).

Despite the limitations, the wealth of historical and archaeological information acquired throughout this research enabled a provisional reconstruction of Chahak crucible steel making method with emphasis on Biruni's recipe. The key factor for the particular

635 relevance of this recipe for Chahak's process is the chromite mineral. The only recipe that offers an ingredient matching the properties of chromium found in the Chahak samples is Biruni's recipe, and only in Chahak do we find evidence for the use of this mineral.

\section{Conclusion}

On the basis of the historical accounts, we identified the historical site of Chahak in

640 Southern Iran. The retrieved material consisted of the broken crucible sherds, slag fins, smithing slags, two tuyères and an iron bloom. Morphological examinations helped reconstructing a typical Chahak crucible, estimating the crucible volume and slag fin volume, and enabled a physical comparison with other known crucible steel making crucibles that showed an overall similarity to the Central Asian crucibles of Uzbekistan and Turkmenistan.

645 This may suggest that people of Chahak were aware of both traditions and adapted some features from each production style to fit within the available resources, and support the operating parameters. 
The chemical analysis of the crucible sherds and other samples, including slag fins, revealed a unique presence of chromite in the slag and chromium in its metal prills. We demonstrated, with direct evidence, that chromite was added as an ingredient, and not accidentally or as an impurity. The modern steel industry categorises steel of such amount of chromium as tool steel, but with further mechanical and thermal treatments, a parameter which could not have been preserved in the production waste. A Persian flint striker of the same time period has been identified to contain chromium in similar amounts, which potentially confirms the production and utilisation of Chahak crucible steel, or Chahak tradition. The crucible steel recipe of Biruni mentions the addition of Chromite.

As far as we are aware, the chromium content in the Chahak prills is exclusively a Persian phenomenon and may serve as an identifier of the Chahak tradition, as opposed to the Uzbek and Turkmen crucible steel traditions. The ingredient rusakhtaj recorded by

660 Biruni is most likely black chromite sand. This strongly supports our interpretation that the chromium content of the Chahak steel is due to the intentional addition of a particular component, making this the first intentionally produced chromium steel. The concurrent use of chromite in Iranian glass and ceramic production, and records of myrobalans and salt in various Indian industries indicate cross-industry and possibly cross continental exchanges of technological know-how, at least in the making of the historical recipes.

This research not only delivers the earliest known evidence for the production of chromium steel, but also provides a chemical tracer that may allow the sourcing of crucible steel artefacts in museums or archaeological collections to Chahak.

\section{Acknowledgements}

The archaeological research is part of the first author's PhD research under the supervision of the second and third authors. This research would not have been possible without the fieldwork and sample transport approvals from Iran's Cultural Heritage, Handicrafts and Tourism Organization and the Iranian Centre for Archaeological Research. Special thanks to Harriet White, Philip Connolly, Kevin Reeves, Tom Gregory, Agnese

675 Benzonelli and Michael Charlton that facilitated my research at the Wolfson Archaeological Science Laboratories of UCL Institute of Archaeology. Last but not least, funding from Qatar Foundation (through UCL Qatar) for supporting the original research, and from the Gerda Henkel Foundation for funding to continue it as a postdoctoral project, is gratefully acknowledged.

\section{Author contributions statement}

R.A. conducted the research as her PhD project, including the technical interpretation of historical texts and analyses of the archaeological samples and results, under the supervision of Th.R. and M.M.T. 


\section{References}

685 Al-Hassan, Y. Iron and steel technology in Medieval Arabic sources. Journal for the History of Arabic Science 2, 31-52 (1978).

Alipour, R., Persian Crucible Steel Production: Chahak Tradition. PhD Thesis. University College London (2017).

Alipour, R. \& Rehren, Th. Persian Pulad production: Chahak tradition. Journal of Islamic 690 Archaeology 1, 231-261 (2014).

Allan, J. \& Gilmour, B. Persian Steel: The Tanavoli Collection (Oxford, 2000).

Ando, T. \& Krauss, G. The isothermal thickening of cementite allotrimorphs in a $1.5 \mathrm{Cr}-1 \mathrm{C}$ steel. Acta Metallurgica 29, 351-363 (1981).

Attarzadeh, P., Karimi, M., Yazdi, M., Khankahdani, K, N. Geochemistry of chromitites in 695 eastern part of Neyriz Ophiolite Complex (Southern Iran). Open Journal of Geology 7, 213233 (2017).

Bayley, J. \& Rehren, Th. Towards a functional and typological classification of crucibles. In: La Niece, S., Hook, D. \& Craddock, P. T. (eds.) Metals and Mines: Studies in Archaeometallurgy. London: Archetype Books, 46-55. (2007).

700 Biruni, M. ibn A. Al-Jamaahir -al-Marefat al-Jawahir, (Translated to Persian by M.A. Najafi, M.A., \& Khalili, M.) (Tehran Economist, 1974).

Biruni, M. ibn A. Al-Jamahir fi al-Jawahir, (ed. Hadi, Y.). (Maktab Nashr al-Turath al-Makhtut, 1995).

Blackelock, E.S. The Early Medieval Cutting Edge of Technology: An archaeometallurgical, 705 technological and social study of the manufacture and use of Anglo-Saxon and Viking iron knives, and their contribution to the early medieval iron economy. PhD Thesis. University of Bradford (2012).

Charlton, M. Ironworking in Northwest Wales: An Evolutionary Analysis, PhD Thesis. University College London (2007).

710 Craddock, P.T. Early Metal Mining and Production. (Edinburgh University Press, 1995).

Craddock, P.T. Cast iron, fined iron, crucible steel: liquid iron in the Ancient World. In:

Mining and Metal Production through the Ages (eds. Craddock, P.T. \& Lang, J.) 231-257 (The British Museum Press, 2003). 
Craddock, P.T. \& Lang, J. Crucible steel - bright steel. Historical Metallurgy 38, 35-46 (2004).

715 Craddock, P.T., Gurjar, L.K. \& Hegde, K.T.M. Zinc production in medieval India, World Archaeology 15/2, 211-217 (1983).

Degarmo, E.P., Black, J.T., \& Kohser, R.A. Materials and Processes in Manufacturing (10th ed.) (Wiley, 2007).

Dehkhoda, A. Lughatnama (Encyclopedic Dictionary). (Tehran: Tehran University Press, 1993).

720 Ellingham, H.J.T. Reducibility of oxides and sulphides in metallurgical processes. J. Soc. Chem. Ind. 63/5, 125-160 (1944).

Feuerbach, A. Crucible steel in Central Asia: Production, Use and Origins. PhD Thesis. University of London (2002).

Feuerbach, A., Merkel, J., \& Griffith, D. Production of crucible steel by co-fusion:

725 archaeometallurgical evidence from the ninth-early tenth century at the site of Merv, Turkmenistan. In: Materials Issues in Art and Archaeology V (eds. Vandiver, P., Druzik, J., Merkel, J., \& Stewart, J.) 105-110 (1997).

Feuerbach, A., Merkel. J. and Griffith, D. An examination of crucible steel in the manufacture of Damascus steel, including evidence from Merv, Turkmenistan. In: Th. Rehren, A.

730 Hauptmann \& J. Muhly (eds.), Metallurgica Antiqua, Der Anschnitt, Beiheft 8, 37-44 (1998).

Freestone, I.C. Refractory materials and their procurement. In: Hauptmann, A. Pernicka, E. and Wagner, G.A. (eds.) Old World Archaeometallurgy. Der Anschnitt, Beiheft 7, 155-162. (Bochum, 1989).

Freestone, I. C. The Relationship between enameling on ceramics and on glass in the Islamic 735 World. Archaeometry 44/2, 251-255 (2002).

Freestone, I.C. and Tite, M.S. Refractories in the ancient and preindustrial World. In: Kingery, W.D. (ed.) High-Technology Ceramics Past, Present and Future. Ceramics and Civilisation III. American Ceramic Society. Westerville, Ohio, 35-64 (1986).

Freestone, I.C., Craddock, P.T., Hedge, K.T.M., Hughes, M.j. \& Paliwal, H.V. Zinc production 740 at Zawar, Rajasthan. In: Furnaces and Smelting Technology in Antiquity (eds. Craddock, P.T., \& Hughes, M.J.) 229-241 (British Museum, 1985).

Gladman, T., The Physical Metallurgy of Microalloyed Steels (The Institute of Materials, 1997).

Gregory, E. Metallurgy (Blackie \& Son Limited, 1932). 
745 Hall, R. Ophiolite-related contact metamorphism: skarns from Neyriz, Iran. Proc. Geol. Ass. 92/4, 231-240 (1981).

Hamester, M.R.R., Balzer, P.S. \& Becker, D. Chemical-mechanical characteristics of crushed oyster-shell. Materials Research 15/2, 204-208 (2012).

Herrmann, G., Kurbansakhatov. K., \& Simpson, St. J. International Merv Project. Preliminary 750 report on the Fifth Season, Iran 35, 10-13 (1997).

Herrmann, G. and Kurbansakhatov, K. The International Merv Project. Preliminary report on the Third Season, Iran 33, 31-60 (1995).

Herrmann, G. Kurbansakhatov, K. and Simpson, St. J. International Merv Project. Preliminary report on the Fourth Season, Iran 34, 1-8 (1996).

Hoyland, R. G., \& Gilmour, B. Medieval Islamic Swords and Swordmaking: Kindi's treatise "On swords and their kinds." (Short Run Press, 2006).

Iles, L. The exploitation of manganese-rich 'ore' to smelt iron in Mwenge, Western Uganda, from the mid second millennium AD. Journal of Archaeological Science 49, 423-441 (2014).

Juleff, G. Crucible steel in Sri Lanka and India: new evidence. Ancient Ceylon 9, 35-59 (1990).

Juleff, G. Early Iron and Steel in Sri Lanka: a Study of the Samanawalewa Area. AVAMaterialien 54, (1998).

Juleff, G., Jaikishan, S., Srinivasan, Sh., Ranganathan, S., \& Gilmour, B. Northern Telangana, an iron and crucible steel production landscape in India. ISIJ International 54/5, 1030-1037 765 (2014).

Killick, D. Social constructionist approaches to the study of technology. World Archaeology 36/4, 571- 578 (2004).

Lang, J., Craddock, P.T. and Simpson, St.J. New evidence for early crucible steel. Historical Metallurgy 32/1, 7-14 (1998).

770 Marcinkowski, M.I. Measures and weights in the Islamic world: an English translation of Walther Hinz's handbook "Islamische Masse und Gewichte" (translated by Walther, H). Kuala Lumpur: International Institute of Islamic Thought and Civilisation (ISTAC). (International Islamic University Malaysia (IIUM), 2003)

Martinón-Torres, M. Why should archaeologists take history and science seriously?. In: M. 775 Martinón-Torres and Th. Rehren (eds). Archaeology, History and Science. Walnut Creek, CA: Left Coast Press, 15-36 (2008).

Martinón-Torres, M. \& Rehren, Th. Technical ceramics. In: Archaeometallurgy in Global 
Perspective: Methods and Syntheses, B.W. Roberts and C.P. Thornton (eds), 107-131. (New York: Springer, 2014).

780 Martinon-Torres, M., Li, XZh., Xia, Y., Benzonelli, A., Bevan, A., Ma, ShT., Huang, JH., Wang, L., Lan, DSh., Liu, JW., Liu, SR., Zhao, Zh., Zhao, K \& Rehren, Th. Surface chromium on Terracotta Army bronze weapons is neither an ancient anti-rust treatment nor the reason for their good preservation. Scientific Reports 9, 5289 (2019).

Mason, R.B., Tite, M.S., Paynter, S., \& Salter, C. Advances in polychrome ceramics in the Islamic world of the 12th century AD. Archaeometry 43/ 2, 191-209 (2001).

Miller, H.M.L. Archaeological approaches to technology. London: Elsevier/Academic Press (2007).

Misra, K.C. Understanding Mineral Deposits (Springer, 2000).

Moore, F., Rajab Zadeh, M.A. First report on platinum-group minerals in chromitites from northwestern Neyriz ophiolite, Iran. J. Sci. I.R.Iran 1/4, 47-54 (1993).

Moreland, J. Archaeology and Text. London: Duckworth (2001).

Morris. J. W. Stronger, tougher steels. Science New Series 320 (5879), 1022-1023 (2008).

Papakhristu, O. \& Rehren, Th. Techniques and technology of ceramic vessel manufacture: Crucibles for wootz smelting in Central Asia. In: Modern Trends in Scientific Studies on 795 Ancient Ceramics (eds. Kilikoglou, V., Hein, A., \& Maniatis, Y.) 69-74 (BAR International Series 1011, 2002).

Principe, L. Chemical translation and the role of impurities in alchemy: Examples from Basil Valentine's Triumph-Wagen. Ambix 34/1, 21-30 (1987).

Rehder, J.E. Ancient carburization of iron to steel. Archeomaterials 3, 27-37 (1989).

800 Rehren, Th. \& Papachristou, O. Similar like white and black: A comparison of steel-making crucibles from Central Asia and the Indian subcontinent. In: Th. Stöllner (ed), Man and Mining: Mensch und Bergbau, 393-404. (Bochum: Deutsches Bergbau-Museum, 2003).

Rehren, Th., and Papakhristu, O. The Ferghana process of crucible steel smelting. Metalla 7, 55-69 (2000).

805 Rehren, Th., Charlton, M., Chirikure, Sh., Humphris, J., Ige, A., \& Veldhuijzen, H.A. Decisions set in slag: the human factor in African iron smelting. In: Metals and Mines: Studies in Archaeometallurgy (eds. La Niece, S., Hook, D., \& Craddock, P.T.) 219-225 (Archetype Books, 2007).

Rostoker, W., \& Bronson, B., Pre-Industrial Iron: its technology and ethnology. 
810 Archeomaterials Monograph No. 1. (Pennsylvania University Press, 1990).

Rye, O.S. Pottery Technology: Principles and Reconstruction (Manuals on Archaeology 4). Fourth edition. Washington, D.C.: Taraxacum (2002).

Scott, D. A. Metallography and Microstructure of Ancient and Historic Metals. Marina del Rey, CA: Getty Conservation Institute (1991).

815 Simpson, St.J. The early Islamic crucible steel industry at Merv. IAMS 21, 14-15 (2001).

Srinivasan, S. Wootz crucible steel: a newly discovered production site in South India. Papers from the Institute of Archaeology. 5, 49-59 (1994).

Srinivasan, S. and Griffiths, D. Crucible steel in south India: preliminary investigations on crucibles from newly identified sites. In: P. Vandiver, J. Druzik, J. Merkel \& J. Stewart (eds), Materials Issues in Art and Archaeology V, 111-125 (1997).

Stewart, J., Charles, J., \& Wallach, E. Iron-phosphorous-carbon system. Part 1. Mechanical properties of low carbon iron-phosphorous alloys. Mater. Sci. Technol. 16, 275-282 (2000).

Truffaut, E., Steelmaking in a bloomery furnace: behaviour of manganese. Research on the Ferrum Noricum process. In: Early Iron in Europe (eds. Rehren, Th., \& Cech, B.) Instrumentum Monographies. 50, 258-300 (2014).

Verhoeven, J.D. Steel metallurgy for the non-metallurgist. ASM International (2007).

Verhoeven, J.D., and Pendray, A.H. Experiments to reproduce the pattern of Damascus steel blades. Materials Characterization 29, 195-212 (1992).

Verhoeven, J.D., Pendray, A.H., Dauksch, W.E. The key role of impurities in ancient 830 Damascus steel swords. The Journal of The Minerals, Metals \& Materials Society JOM. 50/90, 58-64 (1998).

Verhoeven, J.D., Pendray, A.H., Gibson, E.D. Wootz Damascus steel blades. Mater. Charact. 37, 922 (1996).

Wayman, M. and Juleff, G. Crucible steelmaking in Sri Lanka. Historical Metallurgy 33, 26-42 835 (1999).

Yaghubpur, A., Hassannejad, A.A. The Spatial Distribution of Some Chromite Deposits in Iran, Using Fry Analysis. Journal of Sciences, Islamic Republic of Iran 17/2, 147-152 (2006).

Zhou, W., Liu, S., Liu, H., Chen, J. A preliminary study of traditional Chinese crucible lead smelting technology (中国传统坩埚炼铅技术初探). Stud. Hist. Nat. Sci.

840 33, 201-215 (in Chinese) (2014). 